\title{
Mineralogical and Chemical Characteristics of Coal Ashes from Two High-Sulfur Coal-Fired Power Plants in Wuhai, Inner Mongolia, China
}

\author{
Qiang Wei ${ }^{1,2, *,+} \mathbb{C}$ and Weijiao Song ${ }^{1,2, \dagger}$ \\ 1 State Key Laboratory of Coal Resources and Safe Mining, China University of Mining and Technology, \\ Beijing 100083, China; songweijiao87@163.com \\ 2 College of Geoscience and Surveying Engineering, China University of Mining and Technology (Beijing), \\ Beijing 100083, China \\ * Correspondence: $13811880740 @ 126 . c o m$ \\ + These authors contributed equally to this work.
}

Received: 4 March 2020; Accepted: 2 April 2020; Published: 4 April 2020

\begin{abstract}
The mineralogical and chemical characteristics of the feed coals and coal combustion products (CCPs) from two power plants (Xilaifeng and Damo) that consume coals from the Wuda Coalfield, Inner Mongolia, were investigated, using XRD, SEM-EDS, XRF, and ICP-MS. The feed coals from Xilaifeng and Damo are both of high ash yield (52.93\% and $48.36 \%$, respectively), and medium and high total sulfur content $(2.22 \%$ and $3.32 \%$, respectively). The minerals in the feed coals are primarily composed of kaolinite, quartz, illite, pyrite, and, to a lesser extent, gypsum and anatase. In addition to the elevated incompatible elements $(\mathrm{Nb}, \mathrm{Ta}, \mathrm{Zr}, \mathrm{Hf}$ and $\mathrm{Th}), \mathrm{Li}$ and $\mathrm{Hg}$ are enriched in the feed coals from the Xilaifeng and Damo power plants, respectively. Rare earth elements and yttrium (REY) are more enriched in the feed coals from Xilaifeng $(194 \mu \mathrm{g} / \mathrm{g})$ than those of Damo $(93.9 \mu \mathrm{g} / \mathrm{g})$. The inorganic phases of CCPs from both power plants are mainly composed of amorphous phase, quartz, hematite, illite, and anhydrite. Compared with the feed coals, concentrations of most trace elements in the CCPs are elevated, and they are preferentially enriched in the fly ashes relative to the bottom ashes $\left({ }^{*} f / b>1\right)$, especially F, As, Sr, Mo, Se, and $\mathrm{Hg}\left({ }^{*} f / b>2.5\right)$. Furthermore, most trace elements (Xilaifeng: excluding $\mathrm{Li}, \mathrm{Cr}, \mathrm{Co}, \mathrm{Ni}, \mathrm{Rb}, \mathrm{Nb}$ and $\mathrm{Cs}$; Damo: excluding $\mathrm{Li}, \mathrm{V}, \mathrm{Cr}, \mathrm{Co}$, $\mathrm{Ni}, \mathrm{Cu}, \mathrm{Zn}, \mathrm{Ga}, \mathrm{Rb}, \mathrm{Cs}$ and $\mathrm{Ba}$ ) are more enriched in the (fine) fly ashes relative to the laboratory high-temperature coal ashes (HTAs). The REY barely differentiate in either the fly ash or bottom ash from Xilaifeng. In contrast, the REY in the fine and coarse fly ashes from Damo have very similar $\mathrm{H}$-type distribution patterns with negative $\mathrm{Ce}$ and slightly positive $\mathrm{Y}$ anomalies. Attention should be paid to the enriched toxic elements (including F, As and $\mathrm{Hg}$ ) in the fly ashes from both power plants due to possible adverse environmental effect.
\end{abstract}

Keywords: Wuda Coalfield; power plant; coal combustion products; minerals; elements

\section{Introduction}

Global coal demand has rebounded since 2017 and is expected to remain broadly steady in later years [1]. Coal maintained its position as the largest source of electricity in the world, with a $38 \%$ share, and in China with a 67\% share, in 2018 [1]. Although public concerns about air quality arise in China, coal is still likely to play a vital role in sustaining economic growth and safeguarding energy security; and therefore, massive amounts of coal combustion products (CCPs) will be continuously produced in China for a long time. With the expanding application of fly ash for agricultural and industrial uses, caution should also be taken due to the enrichment of toxic substances in the CCPs. Extensive studies have conducted leaching tests in order to investigate the potential environmental impacts during 
beneficial use or land disposal [2-9]. On the other hand, CCPs produced from coal-fired power plants have attracted attentions due to the enrichment of critical elements, such as $\mathrm{Ge}, \mathrm{Ga}$, $\mathrm{Li}$, and rare earth elements and yttrium (REY), relative to the feed coal [10-18].

The Wuda Coalfield, Inner Mongolia, Northern China, is located in the Northwestern Ordos Basin, which is one of the largest coal-bearing basins in China. Like other coals that are enriched in critical metals from Northern China [19-25], the Wuda coal has also been found to be enriched in critical elements, such as rare earth elements and sulfur, with the major forms of pyritic and organic sulfur [26]. This warrants a study on the CCPs from power plants that combust the local coals and products from coal mining and preparation processes, as well as the toxic elements that, in many cases, are enriched in medium and high sulfur coals [27-32].

\section{Wuda Coalfield and the Xilaifeng and Damo Power Plants}

The Wuda Coalfield is located in the Northwestern Wuda District of Wuhai City, Western Inner Mongolia, and it sits at the northwestern margin of the Ordos Basin, which was developed to the west of the Northern China Platform (Figure 1A) [33-35]. The Wuda Coalfield is $10 \mathrm{~km}$ long (N-S) and 3-5 $\mathrm{km}$ wide (W-E), with a total area of $\sim 35 \mathrm{~km}^{2}$. There were approximately 27 coal seams (with a total thickness of $43 \mathrm{~m}$ ) deposited in the Upper Carboniferous Taiyuan Formation and the Lower Permian Shanxi Formation [36]. The major coal-bearing Taiyuan Formation contains five coal seams (Nos. 9, 10, $12,13$ and 15$)$, with variable total sulfur contents $(0.88 \%-3.46 \%)$ and ash yields $(13.10 \%-23.92 \%)$ [35]. The Wuda District borders the Gobi Desert in the west and north, and it borders the Yellow River and Ordos Loess Plateau in the east [36], which is divided into four zones: coal mine area (Wuda Coalfield), industrial park, urban area, and farm land [37]. The Wuda Coalfield is exploited by the Suhaitu, Huangbaici, and Wuhushan Mines (Figure 1B). It is estimated that the coalfield has a total coal reserve of $\sim 600 \mathrm{Mt}$, and it mostly produces bituminous coals used for industrial coking [35,36].

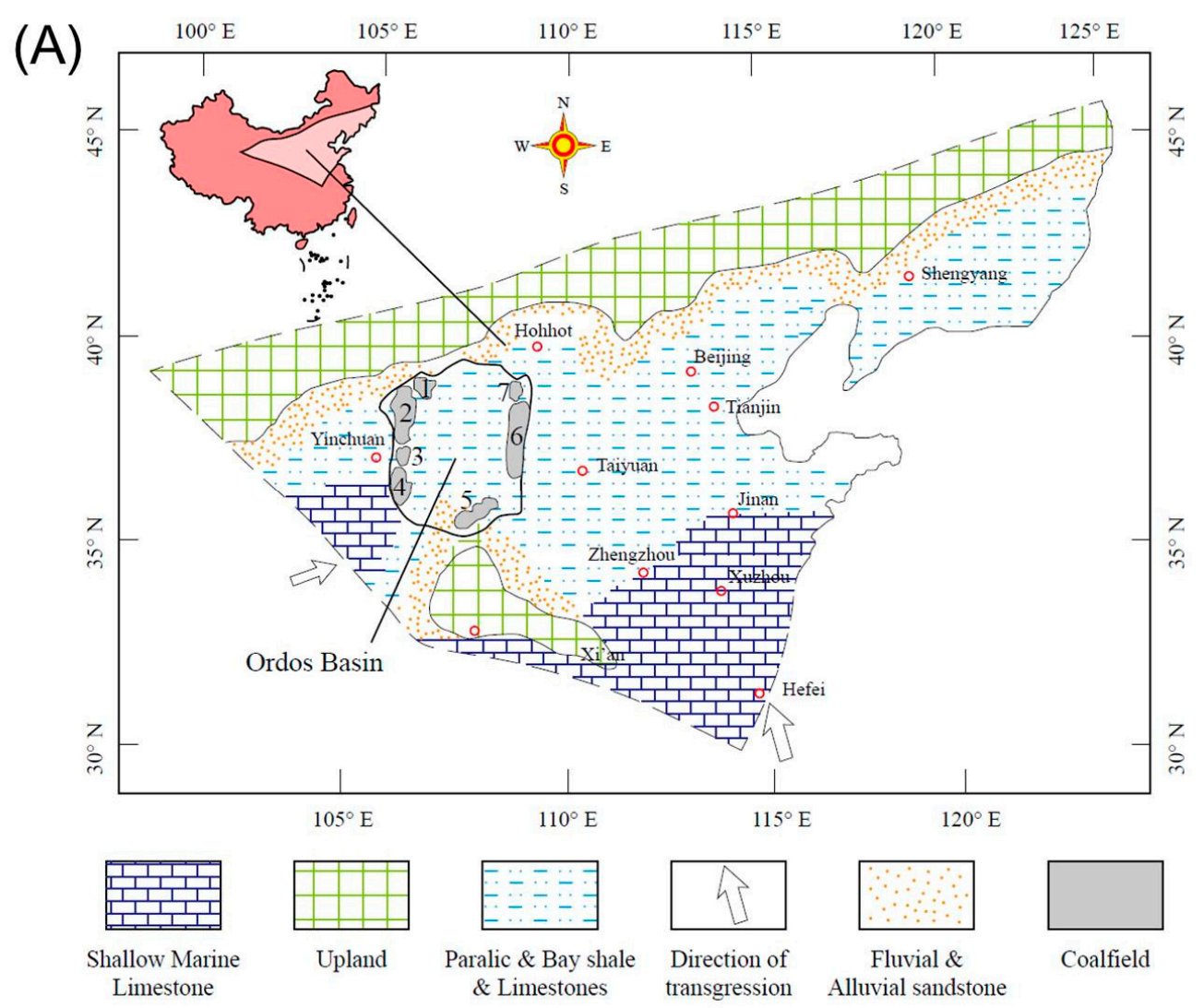

Figure 1. Cont. 


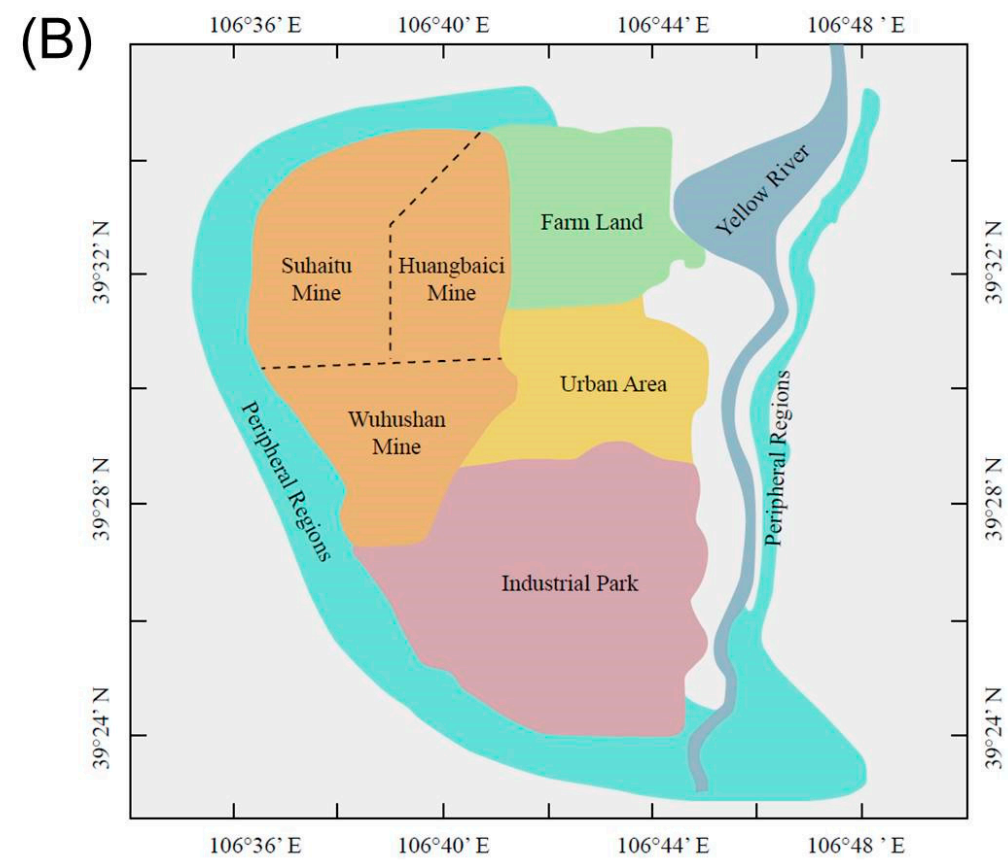

Figure 1. Location of Ordos Basin and the Wuda Coalfield and paleogeographic map of the Late Paleozoic in Northern China (modified after Han and Yang [33]; Liu [34]; and Dai et al. [35]) (1, Wuda Coalfield; 2, Helanshan Coalfield; 3, Hengcheng Coalfield; 4, Weizhou Coalfield; 5, Weibei Coalfield; 6, Hedong Coalfield; and 7, Junger Coalfield) (A), and the division of Wuda District, Wuhai City, Inner Mongolia (modified after Cao et al. [37]) (B).

Samples collected from the Xilaifeng and Damo power plants are investigated in the present study, and the feed coals for both power plants are originally from the Suhaitu, Huangbaici, and Wuhushan mines. The mineralogy and elemental geochemistry of the coals from the Wuda Coalfield have been previously studied [26]. The power-generating capacity of the Xilaifeng Power Plant is 2.2 billion $\mathrm{kW} \cdot \mathrm{h}$ per year $(2 \times 200 \mathrm{MW}$ generator set for the first-stage construction). Two circulating fluidized bed boilers can be utilized to burn coal gangue, and the furnace temperature is about $900{ }^{\circ} \mathrm{C}$. The efficiency of the limestone desulfurization system is above $98 \%$, and over $99 \%$ fly ash can be collected by the bag house filter. The particle size of the feed coal is $<9 \mathrm{~mm}$, and the production ratio of bottom ash to fly ash is around 3:2. In comparison, the generating capacity of the Damo Power Plant is 0.45 billion $\mathrm{kW} \cdot \mathrm{h}$ per year $(2 \times 25 \mathrm{MW}$ condensing steam turbo-generator set). Two circulating fluidized bed boilers are installed, and the temperature at the upper zone of the furnace is around $900{ }^{\circ} \mathrm{C}$. Ninety-nine percent of the fly ash is collected by the electrostatic precipitator, and sulfur emission is lower than $400 \mathrm{mg} / \mathrm{m}^{3}$ after processing, using the wet flue gas desulfurization technique. The particle size of the feed coal is $<8 \mathrm{~mm}$, and the production ratio of bottom ash to fly ash is around 1:2.

\section{Sampling and Analytical Methods}

Sampling for the present study lasted for seven days in a row. Two feed coals were collected in the morning and afternoon, respectively, each day at the Xilaifeng Power Plant, and two fly ash samples and two bottom ash samples were collected for each generator set each day. At the Damo Power Plant, one feed coal sample was collected each day for seven days. On the first day, one bottom ash sample was collected; and on the fifth day, one coarse fly ash sample, one fine fly ash sample, and one bottom ash sample were collected. On the other five days, two coarse fly ash samples, two fine fly ash samples, and two bottom ash samples were collected each day. Thus, in summary, 14 feed coal samples, 28 fly ash samples, and 28 bottom ash samples were collected at the Xilaifeng Power Plant. Seven feed coal samples and 34 ash samples (including 11 fine fly ashes, 11 coarse fly ashes, and 12 bottom ashes) were collected at the Damo Power Plant. All samples (Table S1) were stored in 
plastic bags, to avoid contamination, and the feed coal and bottom ash samples were air-dried and crushed to minus 200-mesh for subsequent analyses.

Proximate analysis for feed coal samples was conducted while following ASTM Standards D3173-11, D3174-11 and D3175-11 [38-40] to determine moisture, ash yield, and volatile matter, respectively, and the total sulfur content was determined based on ASTM Standard D3177-02 [41].

The mineralogical composition was determined by powder X-ray diffraction (XRD), along with a field-emission-scanning electron microscope (FEI Quanta ${ }^{\mathrm{TM}} 650$ FEG) (FEI Company, Hillsboro, OR, USA) equipped with an EDAX energy-dispersive X-ray spectrometer (SEM-EDS). Low-temperature ashing of feed coal samples was carried out, using an EMITECH K1050X plasma asher (Quorum Technologies Ltd., Laughton, UK). XRD analysis of the low-temperature ashes (LTA) and the coal combustion products (CCPs) was performed by using a D/max-2500/PC powder diffractometer with $\mathrm{Ni}$-filtered $\mathrm{Cu}-\mathrm{K} \alpha$ radiation. With a step size of $0.01^{\circ}$, each XRD pattern was recorded over a $2 \theta$ interval of $2.6^{\circ}-70^{\circ}$, and each X-ray diffractogram was subjected to quantitative analysis, using Siroquant ${ }^{\mathrm{TM}}$ software (Siroquant, Canberra, Australia) developed by Taylor [42], based on the principles for diffractogram profiling proposed by Rietveld [43]. For the SEM-EDS study, the fly ash samples were prepared as grain mounts and coated with carbon, using a sputtering coater (Quorum Q150T ES) (Quorum Technologies Ltd., Laughton, UK). The working distance of the SEM-EDS was $10 \mathrm{~mm}$, and the beam voltage was set as $20.0 \mathrm{kV}$.

X-ray fluorescence spectrometry (ARL ADVANT'XP + XRF) (Thermo Fisher Scientific, Waltham, MA, USA) was used to determine the major-element oxides for the laboratory high-temperature ashes (HTAs). For the acquisition of HTAs, minus 200-mesh coals were combusted in a muffle furnace, at $750{ }^{\circ} \mathrm{C}$, for four hours, to achieve constant weight. The contents of residual organic matter (ROM) in the CCPs were also determined at this temperature.

Inductively coupled plasma mass spectrometry (X series II ICP-MS) (Thermo Fisher Scientific, Waltham, MA, USA) was used to determine the concentrations of trace elements in samples (except for $\mathrm{Hg}$ and F), following the method described by Dai et al., [44]. Samples were digested at first by applying an UltraClave Microwave High Pressure Reactor (Milestone). The digestion reagents for each $50 \mathrm{mg}$ feed coal sample were $5 \mathrm{~mL} 65 \% \mathrm{HNO}_{3}$ and $2 \mathrm{~mL} \mathrm{40 \%} \mathrm{HF}$, and for each $50 \mathrm{mg} \mathrm{CCP}$ sample, they were $2 \mathrm{~mL} 65 \% \mathrm{HNO}_{3}$ and $5 \mathrm{~mL} \mathrm{40 \%} \mathrm{HF}$. The Guaranteed-Reagent $\mathrm{HNO}_{3}$ and $\mathrm{HF}$ used for digestion were further purified by sub-boiling distillation. Multi-element standards (Inorganic Ventures: CCS-1, 4, 5 and 6) were used for calibration of trace element concentrations. Arsenic and Se were determined by ICP-MS, using collision cell technology (CCT), in order to avoid disturbance of polyatomic ions [45]. Mercury was determined by using a Milestone DMA- 80 analyzer. Solid samples were directly heated, and the evolved $\mathrm{Hg}$ was selectively captured as an amalgam and measured by atomic absorption spectrophotometry [46]. Fluorine was determined by pyrohydrolysis, in conjunction with an ion-selective electrode, following ASTM Standard D5987-96 [47].

\section{Results and Discussion}

\subsection{Proximate Analysis and Total Sulfur Content of Feed Coals}

The feed coals from Xilaifeng and Damo are of identical moisture content (both $1.07 \%$ on average, and varying from $0.60 \%$ to $1.94 \%$ and from $0.95 \%$ to $1.22 \%$, respectively; Table 1 and Table S2). The ash yield and volatile matter yield of the feed coals from Xilaifeng (52.93\% and $40.11 \%$ on average, respectively; Table 1 and Table S2) are comparable to, but a bit higher than, those of Damo (48.36\% and $36.52 \%$, respectively; Table 1 and Table S2). Compared with the ash yields of the main coal seams (No. 9 seam: 13.10\%; No. 10 seam: 19.67\%) of the Wuda Coalfield [35], their high ash yields are due to the admixture of coal gangue and coal slime into raw coal before combustion. The medium and high total sulfur contents of feed coals from both power plants $(2.22 \%$ and $3.32 \%$, respectively; Table 1 and Table S2) are in accordance with the high sulfur (3.46\% and 3.42\%, respectively) in the main coal seams (Nos. 9 and 10 seams) of the Wuda Coalfield [35]. 
Table 1. Average values of proximate analysis (\%) and total sulfur (\%) of feed coals from the Xilaifeng and Damo power plants.

\begin{tabular}{ccccc}
\hline \multirow{2}{*}{ Power Plant } & \multicolumn{3}{c}{ Proximate Analysis (\%) } & \multirow{2}{*}{$\boldsymbol{S}_{\boldsymbol{t}, \boldsymbol{d}} \mathbf{( \% )}$} \\
\cline { 2 - 4 } & $\boldsymbol{M}_{\boldsymbol{a d}}$ & $\boldsymbol{A}_{\boldsymbol{d}}$ & $\boldsymbol{V}_{\boldsymbol{d a f}}$ & \\
\hline Xilaifeng $^{a}$ & $1.07(0.31)$ & $52.93(6.99)$ & $40.11(3.87)$ & $2.22(0.62)$ \\
Damo $^{b}$ & $1.07(0.09)$ & $48.36(4.67)$ & $36.52(1.97)$ & $3.32(0.60)$ \\
\hline
\end{tabular}

Notes: ${ }^{a}$, average of 14 feed coal samples; ${ }^{b}$, average of 7 feed coal samples; $M$, moisture; $A$, ash yield; $V$, volatile matter; $S_{t}$, total sulfur; $a d$, air-dry basis; $d$, dry basis; $d a f$, dry and ash-free basis. The standard deviations are provided in parentheses.

\subsection{Mineralogical Features of Feed Coals}

The minerals in the feed coals from Xilaifeng and Damo are both primarily composed of kaolinite, quartz, illite, pyrite, and, to a lesser extent, gypsum and anatase (Table 2, Tables S3 and S4; Figure 2). Kaolinite is dominant in coals from both power plants (72.8\% and $69.3 \%$, respectively), and pyrite contents in the feed coals from Xilaifeng are apparently less than those from Damo $(3.9 \%$ and $7.3 \%$, respectively; Table 2), and this is the cause for lower total sulfur content of the feed coals from Xilaifeng relative to that of Damo (Table 1). Besides, the feed coals from Xilaifeng contain small proportions of boehmite, dolomite, and calcite; and trace amounts of anhydrite and diaspore were detected in the low-temperature ashes of feed coals from Damo (Table 2, Tables S3 and S4).

Table 2. Average values of mineralogical compositions of the low-temperature ashes (LTAs) of feed coals (wt.\%) for the Xilaifeng and Damo power plants by XRD and Siroquant analysis.

\begin{tabular}{cccccc}
\hline Power Plant & Kaolinite & Quartz & Illite & Pyrite & Gypsum \\
\hline Xilaifeng $^{a}$ & 72.8 & 9.0 & 8.9 & 3.9 & 2.7 \\
Damo $^{b}$ & 69.3 & 12.8 & 8.5 & 7.3 & 1.9 \\
\hline Boehmite & Anatase & Dolomite & Calcite & Anhydrite & Diaspore \\
\hline 2.2 & 0.3 & 0.1 & $<0.1$ & & \\
& $<0.1$ & & & 0.1 & $<0.1$ \\
\hline
\end{tabular}

Notes: ${ }^{a}$, average of 14 feed coal samples; ${ }^{b}$, average of 7 feed coal samples. The individual feed coal samples are of similar mineralogical compositions (see Tables S3 and S4).

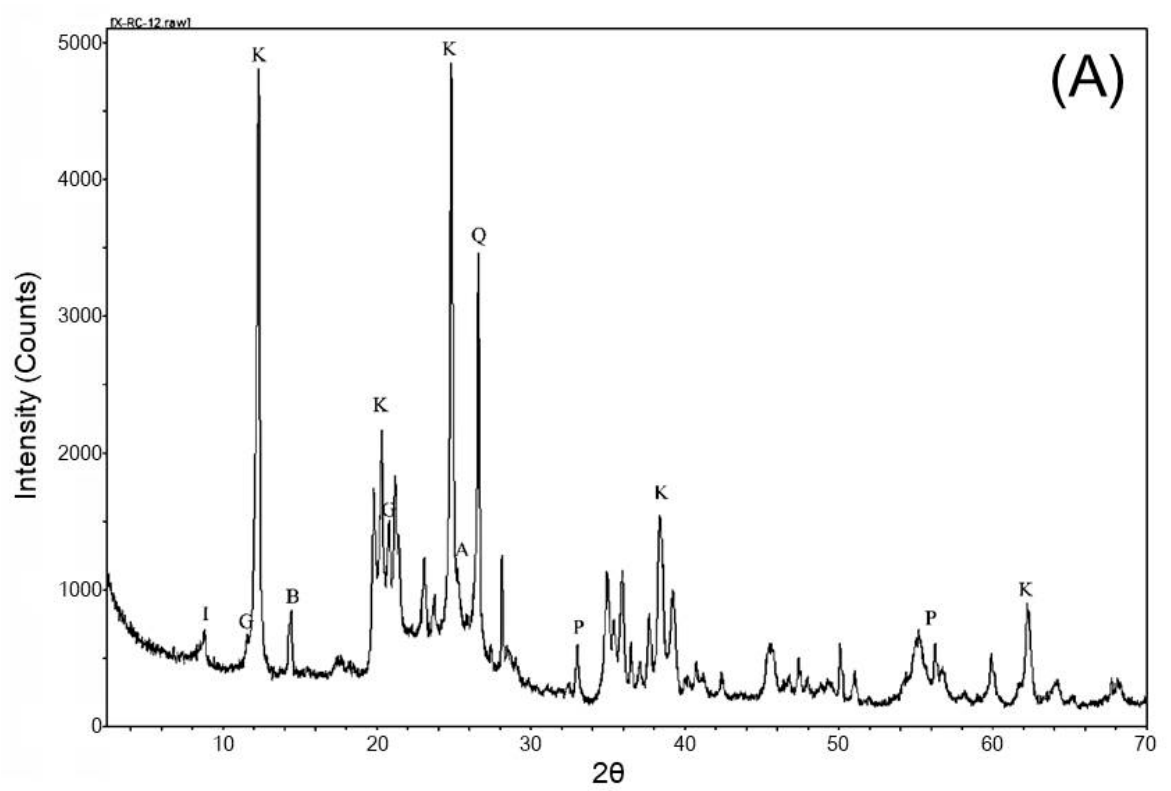

Figure 2. Cont. 


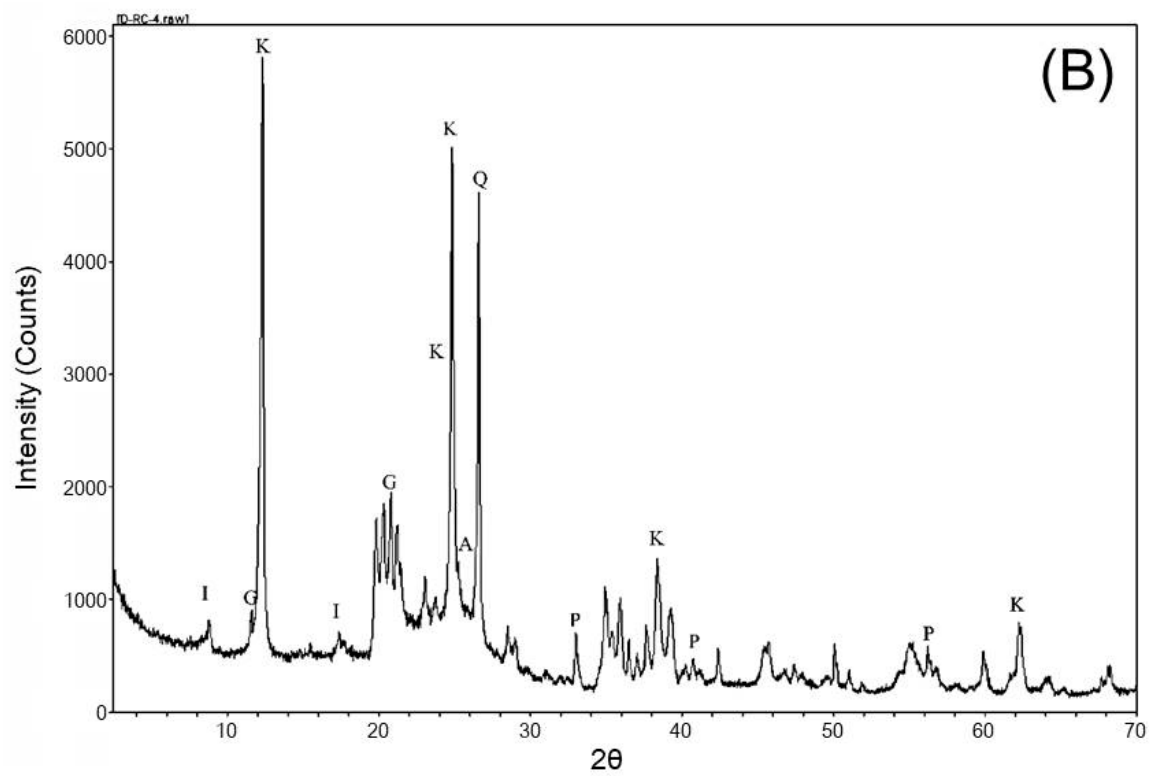

Figure 2. Powder XRD patterns of LTAs of the feed coals from the Xilaifeng and Damo power plants. (A) X-rc-12; (B) d-rc-4. K, kaolinite; P, pyrite; I, illite; Q, quartz; G, gypsum; B, boehmite; and A, anatase.

\subsection{Major and Trace Elements in the Feed Coals}

The element concentrations and their distributions in the CCPs are not only controlled by the type of boiler and dust collection system, but are also largely depended on the element contents and their modes of occurrence in the feed coals [48-52].

The contents of $\mathrm{Al}_{2} \mathrm{O}_{3}, \mathrm{SiO}_{2}, \mathrm{~K}_{2} \mathrm{O}$, and $\mathrm{TiO}_{2}$ in the feed coals for both power plants (Table 3, Tables S5 and S6; Figure 3) are higher than corresponding values of common Chinese coals [53]. Their concentration coefficients (CC, element concentration in feed coal vs. Chinese coal [29]) for Xilaifeng are 3.31, 3.22, 2.72, and 2.35, respectively, and for Damo are 2.77, 2.98, 3.63, and 1.81, respectively (Table 3; Figure 3). Compared with the average Chinese coals [53], $\mathrm{Na}_{2} \mathrm{O}, \mathrm{CaO}, \mathrm{MnO}$, and $\mathrm{Fe}_{2} \mathrm{O}_{3}$ in the feed coals from Xilaifeng and Damo are depleted, and $\mathrm{MgO}$ and $\mathrm{P}_{2} \mathrm{O}_{5}$ are slightly enriched (Table 3; Figure 3).

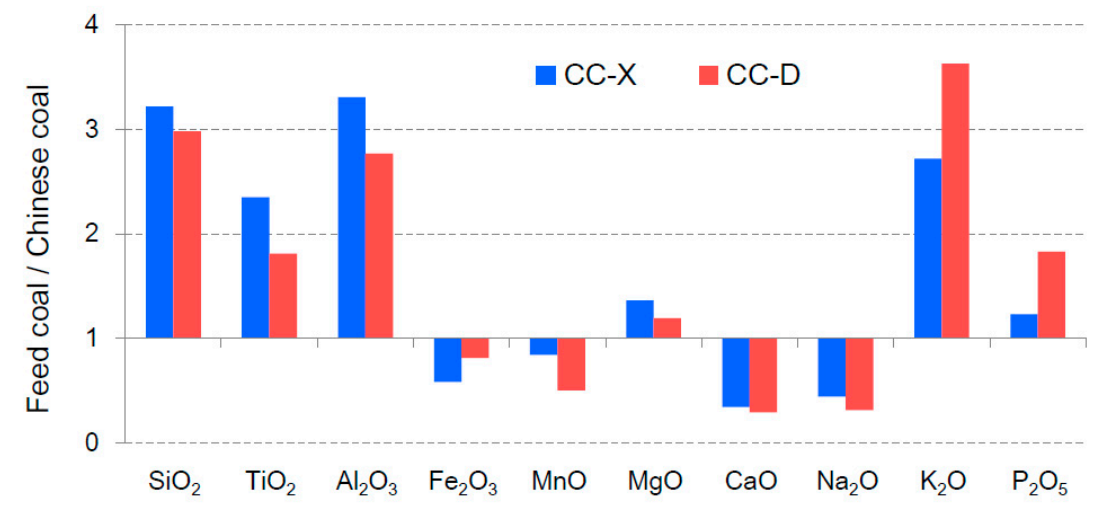

Figure 3. Average concentration coefficient (CC, feed coal vs. Chinese coal) of major elements in the feed coals from the Xilaifeng $(X)$ and Damo (D) power plants.

Compared with world coals [54], the feed coals from both power plants are enriched in incompatible elements, including Nb, Ta, Zr, Hf, and Th (Table 3, Tables S5 and S6; Figure 4). Lithium (CC = 19.04) and $\mathrm{Hg}(C \mathrm{C}=6.10)$ in the feed coals from Xilaifeng and Damo, respectively, are highly enriched (Table 3; Figure 4). The concentrations of other trace elements in the feed coals from both power plants are either slightly elevated or comparable to those in the world coals (Table 3, Tables S5 and S6; Figure 4). 
Table 3. Average concentrations of major $(\%)$ and trace $(\mu \mathrm{g} / \mathrm{g})$ elements in the feed coals from the Xilaifeng and Damo power plants.

\begin{tabular}{|c|c|c|c|c|c|c|c|}
\hline Element & Coal-X & Coal-D & Coal Ash-X & Coal Ash-D & World Coal $^{a}$ & CC-X & CC-D \\
\hline $\mathrm{Al}_{2} \mathrm{O}_{3}$ & 19.79 & 16.54 & 37.4 & 34.24 & 5.98 & 3.31 & 2.77 \\
\hline $\mathrm{CaO}$ & 0.41 & 0.36 & 0.81 & 0.74 & 1.23 & 0.34 & 0.29 \\
\hline $\mathrm{Fe}_{2} \mathrm{O}_{3}$ & 2.81 & 3.95 & 5.33 & 8.23 & 4.85 & 0.58 & 0.81 \\
\hline $\mathrm{K}_{2} \mathrm{O}$ & 0.52 & 0.69 & 0.97 & 1.41 & 0.19 & 2.72 & 3.63 \\
\hline $\mathrm{MgO}$ & 0.30 & 0.26 & 0.57 & 0.54 & 0.22 & 1.36 & 1.19 \\
\hline $\mathrm{MnO}$ & 0.01 & 0.01 & 0.02 & 0.02 & 0.015 & 0.84 & 0.50 \\
\hline $\mathrm{Na}_{2} \mathrm{O}$ & 0.07 & 0.05 & 0.13 & 0.10 & 0.16 & 0.44 & 0.31 \\
\hline $\mathrm{P}_{2} \mathrm{O}_{5}$ & 0.11 & 0.17 & 0.22 & 0.34 & 0.092 & 1.23 & 1.83 \\
\hline $\mathrm{SiO}_{2}$ & 27.24 & 25.26 & 51.37 & 52.18 & 8.47 & 3.22 & 2.98 \\
\hline $\mathrm{TiO}_{2}$ & 0.77 & 0.60 & 1.47 & 1.24 & 0.33 & 2.35 & 1.81 \\
\hline As & 6.61 & 7.85 & 12.5 & 16.2 & 7.6 & 0.87 & 1.03 \\
\hline $\mathrm{Ba}$ & 116 & 164 & 219 & 340 & 150 & 0.77 & 1.10 \\
\hline Be & 3.09 & 2.59 & 5.84 & 5.36 & 1.2 & 2.58 & 2.16 \\
\hline $\mathrm{Bi}$ & 0.75 & 0.84 & 1.42 & 1.74 & 0.84 & 0.89 & 1.00 \\
\hline $\mathrm{Cd}$ & 0.44 & 0.31 & 0.83 & 0.64 & 0.24 & 1.83 & 1.29 \\
\hline Co & 6.39 & 5.92 & 12.1 & 12.2 & 4.2 & 1.52 & 1.41 \\
\hline $\mathrm{Cr}$ & 21.7 & 25.3 & 41.1 & 52.3 & 15 & 1.45 & 1.69 \\
\hline Cs & 1.68 & 3.10 & 3.17 & 6.41 & 0.98 & 1.71 & 3.16 \\
\hline $\mathrm{Cu}$ & 18.7 & 29.2 & 35.4 & 60.3 & 15 & 1.25 & 1.94 \\
\hline $\mathrm{F}$ & 270 & 386 & 510 & 798 & 90 & 3.00 & 4.29 \\
\hline $\mathrm{Ga}$ & 25.1 & 14.5 & 47.4 & 29.9 & 5.5 & 4.57 & 2.63 \\
\hline $\mathrm{Ge}$ & 1.54 & 1.83 & 2.91 & 3.78 & 2 & 0.77 & 0.92 \\
\hline Hf & 7.19 & 4.78 & 13.6 & 9.88 & 1.2 & 5.99 & 3.98 \\
\hline $\mathrm{Hg}$ & 0.32 & 0.61 & 0.60 & 1.26 & 0.1 & 3.20 & 6.10 \\
\hline In & 0.10 & 0.07 & 0.19 & 0.14 & 0.021 & 4.76 & 3.33 \\
\hline $\mathrm{Li}$ & 190 & 44.7 & 360 & 92.4 & 10 & 19.04 & 4.47 \\
\hline Mo & 4.28 & 3.80 & 8.09 & 7.86 & 2.2 & 1.95 & 1.73 \\
\hline $\mathrm{Nb}$ & 19.7 & 12.5 & 37.3 & 25.9 & 3.3 & 5.98 & 3.79 \\
\hline $\mathrm{Ni}$ & 16.7 & 13.8 & 31.6 & 28.5 & 9 & 1.86 & 1.53 \\
\hline $\mathrm{Pb}$ & 29.0 & 29.6 & 54.9 & 61.2 & 6.6 & 4.40 & 4.49 \\
\hline $\mathrm{Rb}$ & 16.5 & 29.0 & 31.2 & 60.0 & 10 & 1.65 & 2.90 \\
\hline $\mathrm{Sb}$ & 0.55 & 0.55 & 1.04 & 1.14 & 0.84 & 0.65 & 0.65 \\
\hline Sc & 8.34 & 2.41 & 15.8 & 4.98 & 4.1 & 2.03 & 0.59 \\
\hline $\mathrm{Se}$ & 4.07 & 3.75 & 7.69 & 7.75 & 1 & 4.07 & 3.75 \\
\hline Sn & 3.61 & 2.87 & 6.82 & 5.93 & 0.79 & 4.57 & 3.63 \\
\hline $\mathrm{Sr}$ & 174 & 67.3 & 329 & 139 & 120 & 1.45 & 0.56 \\
\hline Ta & 1.31 & 1.05 & 2.47 & 2.17 & 0.26 & 5.04 & 4.04 \\
\hline Th & 19.3 & 7.62 & 36.5 & 15.8 & 3.3 & 5.85 & 2.31 \\
\hline $\mathrm{Tl}$ & 0.41 & 1.14 & 0.77 & 2.36 & 0.68 & 0.60 & 1.68 \\
\hline $\mathrm{U}$ & 6.68 & 5.11 & 12.6 & 10.6 & 2.9 & 2.30 & 1.76 \\
\hline $\mathrm{V}$ & 46.8 & 57.1 & 88.5 & 118 & 22 & 2.13 & 2.59 \\
\hline $\mathrm{Zn}$ & 36.2 & 26.3 & 68.4 & 54.3 & 18 & 2.01 & 1.46 \\
\hline $\mathrm{Zr}$ & 266 & 177 & 502 & 366 & 35 & 7.59 & 5.06 \\
\hline $\mathrm{La}$ & 34.1 & 16.4 & 64.3 & 33.8 & 10 & 3.41 & 1.64 \\
\hline $\mathrm{Ce}$ & 75.3 & 43.0 & 142 & 88.9 & 22 & 3.42 & 1.96 \\
\hline $\operatorname{Pr}$ & 7.56 & 3.52 & 14.3 & 7.28 & 3.5 & 2.16 & 1.01 \\
\hline $\mathrm{Nd}$ & 28.7 & 13.5 & 54.2 & 27.9 & 11 & 2.61 & 1.22 \\
\hline Sm & 5.31 & 2.36 & 10.0 & 4.88 & 1.9 & 2.79 & 1.24 \\
\hline $\mathrm{Eu}$ & 1.01 & 0.43 & 1.91 & 0.89 & 0.5 & 2.02 & 0.86 \\
\hline $\mathrm{Gd}$ & 5.89 & 2.40 & 11.1 & 4.96 & 2.6 & 2.27 & 0.92 \\
\hline $\mathrm{Tb}$ & 0.81 & 0.29 & 1.53 & 0.60 & 0.32 & 2.53 & 0.91 \\
\hline Dy & 4.86 & 1.69 & 9.18 & 3.49 & 2 & 2.43 & 0.85 \\
\hline $\mathrm{Y}$ & 23.5 & 7.99 & 44.4 & 16.5 & 8.6 & 2.73 & 0.93 \\
\hline Ho & 0.90 & 0.30 & 1.70 & 0.62 & 0.5 & 1.80 & 0.60 \\
\hline Er & 2.73 & 0.92 & 5.16 & 1.90 & 0.85 & 3.21 & 1.08 \\
\hline $\mathrm{Tm}$ & 0.37 & 0.12 & 0.70 & 0.25 & 0.31 & 1.19 & 0.39 \\
\hline $\mathrm{Yb}$ & 2.65 & 0.88 & 5.01 & 1.82 & 1 & 2.65 & 0.88 \\
\hline $\mathrm{Lu}$ & 0.37 & 0.12 & 0.70 & 0.25 & 0.19 & 1.95 & 0.63 \\
\hline Ash yield (\%) & 52.93 & 48.36 & & & & & \\
\hline
\end{tabular}

Coal- $X$, average of 14 feed coal samples from Xilaifeng; Coal-D, average of 7 feed coal samples from Damo; Coal ash-X/D, average element concentrations on the high-temperature ash basis for Xilaifeng or Damo; CC-X/D, concentration coefficient (CC) of elements in the feed coals from Xilaifeng or Damo. ${ }^{a}$ Average concentrations of major element oxides in Chinese coals [53] and trace elements in world low-rank coals [54] listed for comparison. 


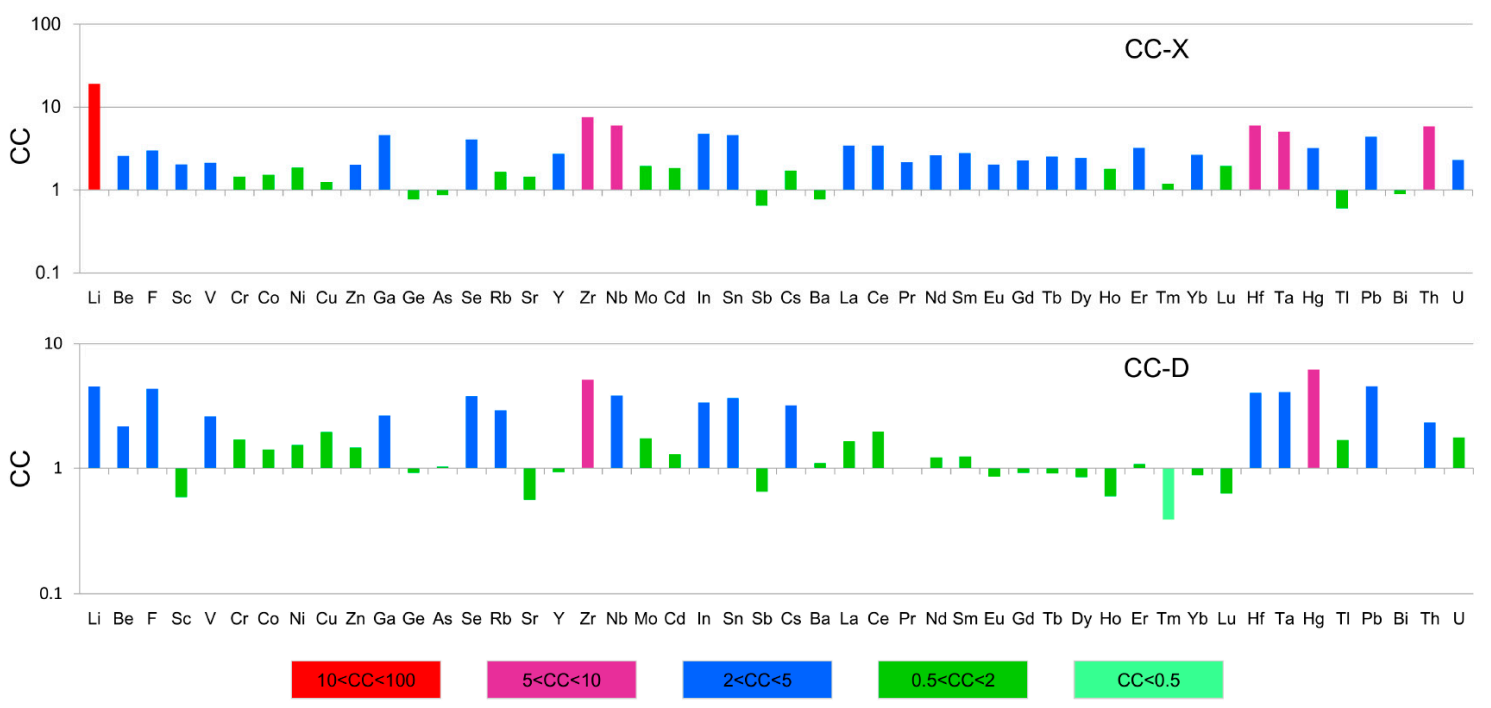

Figure 4. Average concentration coefficient (CC, feed coal vs. world coal) of trace elements in the feed coals from the Xilaifeng $(X)$ and Damo (D) power plants.

Although the feed coals for both power plants are of the same sources (i.e., the three mines of the Wuda Coalfield), the contents of rare earth elements and yttrium (REY) in the feed coals from Xilaifeng (194 $\mu \mathrm{g} / \mathrm{g})$ are much higher than those from Damo $(93.9 \mu \mathrm{g} / \mathrm{g})$ (Table 3, Tables S5 and S6; Figure 5), and this difference is probably caused by different amounts of coal gangue admixture in the feed coals; however, the distribution patterns of REY in the feed coals (normalized to upper continental crust [55]) from the two power plants are quite similar, with positive Ce and Gd anomalies and weak differentiation between light-, medium-, and heavy-REY (Figure 5; threefold classification of REY by Seredin and Dai [15]), and these REY characteristics support the same sources of feed coals. The positive Gd anomaly (Figure 5) is probably attributed to the influence of seawater, hydrothermal fluids, and/or other waters [56], which is in accordance with the sulfur isotope evidences [35].

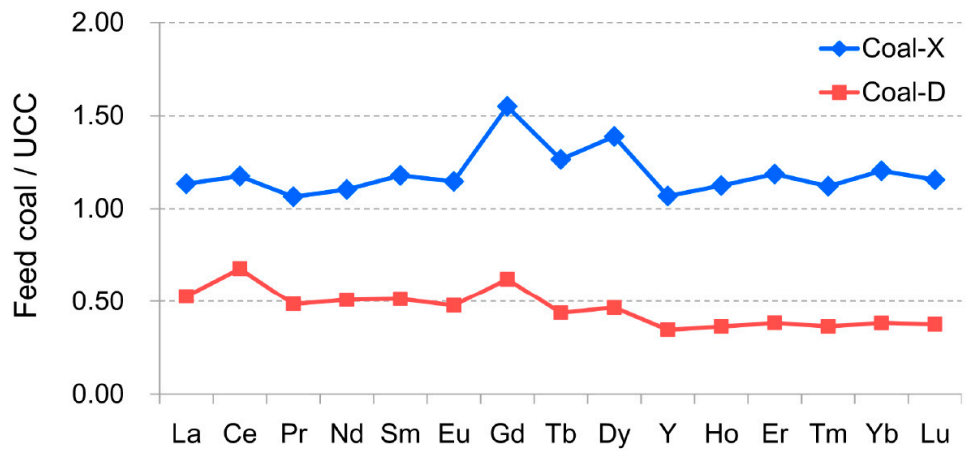

Figure 5. Distribution patterns of rare earth elements and yttrium (REY) in the feed coals (on average) from the Xilaifeng $(X)$ and Damo (D) power plants. REY are normalized to upper continental crust (UCC) [55].

\subsection{Mineralogical Features of CCPs}

The residual organic matter (ROM) in the CCPs indicates inefficiency in combustion [57]. For both power plants, higher ROM contents of fly ashes relative to that of bottom ashes (Xilaifeng: $7.07 \%$ to $2.29 \%$; Damo: $12.44 \%$ and $11.23 \%$ to $4.02 \%$; Table 4 and Tables S7-S11) indicate that the fly ashes contain more organic matter. Higher ROM values of the fly and bottom ashes from Damo relative to those of Xilaifeng suggest that the feed coals were burnt more thoroughly at the Xilaifeng Power Plant. 
Table 4. Average values of mineralogical compositions of coal combustion products (CCPs) from the Xilaifeng and Damo power plants (\%).

\begin{tabular}{|c|c|c|c|c|c|c|c|c|c|c|c|c|c|}
\hline Power Plant & Sample & ROM (\%) & Glass Phase & Quartz & Hematite & Illite & Anhydrite & Gypsum & Siderite & Calcite & Lime & Diaspore & Rutile \\
\hline \multirow{2}{*}{ Xilaifeng } & FA-X ${ }^{a}$ & 7.07 & 63.7 & 5.3 & 8.0 & 6.0 & 12.1 & & & 2.6 & 2.2 & $<0.1$ & \\
\hline & $\mathrm{BA}-\mathrm{X}^{b}$ & 2.29 & 72.6 & 12.4 & 3.0 & 5.6 & 5.8 & & & 0.2 & 0.3 & & 0.1 \\
\hline \multirow{3}{*}{ Damo } & $\mathrm{FA}(\mathrm{F})-\mathrm{D}^{c}$ & 12.44 & 76.0 & 7.1 & 10.5 & 2.9 & 0.9 & 2.5 & 0.2 & & & & \\
\hline & $\mathrm{FA}(\mathrm{C})-\mathrm{D}^{d}$ & 11.23 & 70.6 & 10.3 & 14.4 & 2.5 & 0.8 & 1.5 & & & & & \\
\hline & $\mathrm{BA}-\mathrm{D}^{e}$ & 4.02 & 63.2 & 22.0 & 4.0 & 9.5 & 1.0 & & & & & & 0.3 \\
\hline
\end{tabular}

FA-X, fly ash from Xilaifeng; BA-X, bottom ash from Xilaifeng; FA(F)-D, fine fly ash from Damo; FA(C)-D, coarse fly ash from Damo; BA-D, bottom ash from Damo; ROM, residual organic matter. ${ }^{a}$, average of 28 fly ash samples; ${ }^{b}$, average of 28 bottom ash samples; ${ }^{c}$, average of 11 fine fly ash samples; ${ }^{d}$, average of 11 coarse fly ash samples; ${ }^{e}$, average of 12 bottom ash $^{\circ}$ samples. The individual CCP samples are of similar mineralogical compositions (see Tables S7-S11). 
The inorganic phases of CCPs from both power plants are mainly composed of glass, quartz, hematite, illite, and anhydrite (Table 4 and Tables S7-S11; Figure 6). Small proportions of calcite, lime, diaspore, and rutile can be observed in the fly ashes and/or bottom ashes from Xilaifeng (Table 4, Tables S7 and S8). A fraction of gypsum exists in the fly ashes from Damo, and traces of siderite and rutile are detected in the fine fly ashes and bottom ashes from Damo, respectively (Table 4 and Tables S9-S11).
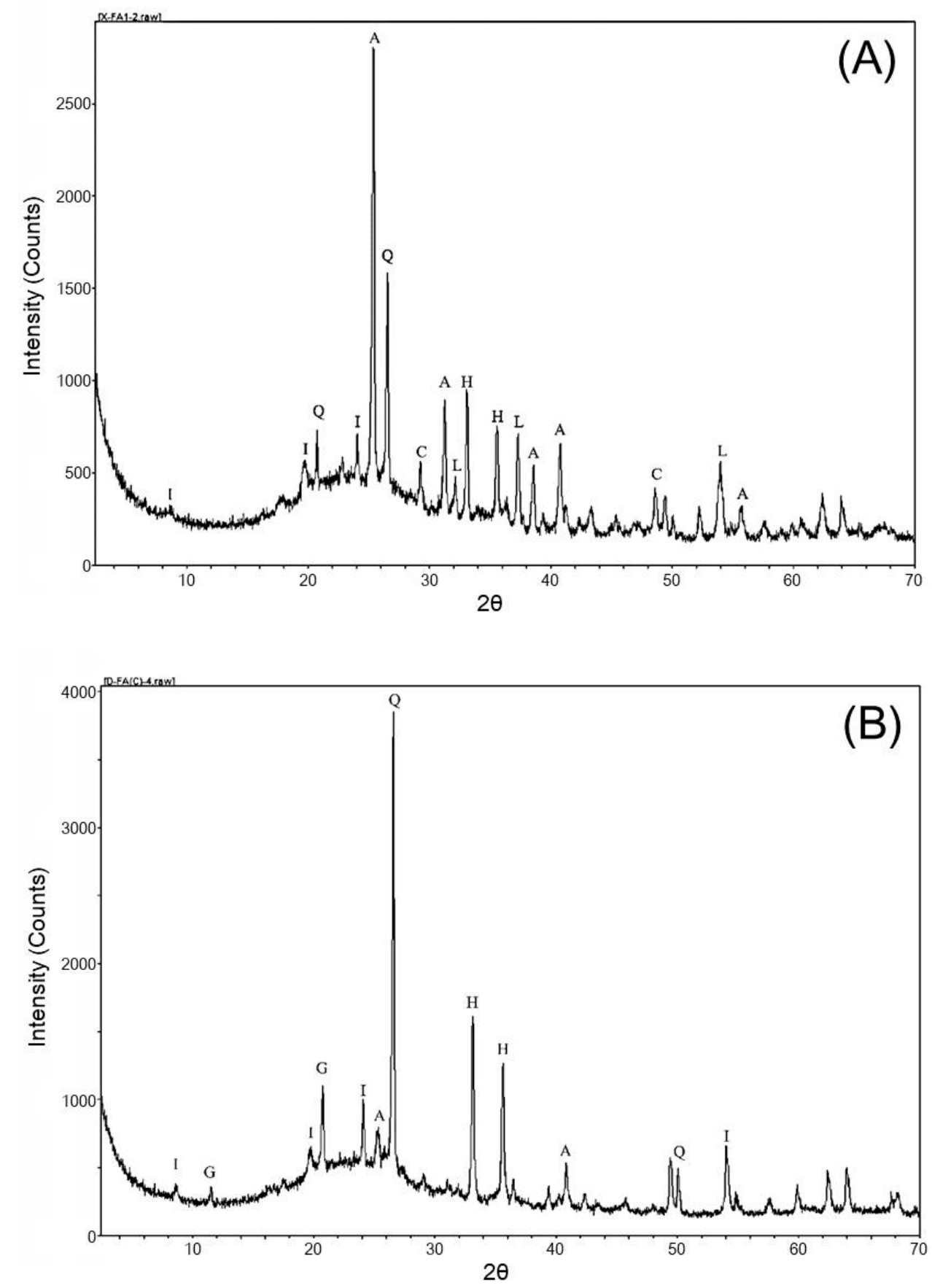

Figure 6. Powder XRD patterns of the fly ashes from the Xilaifeng and Damo power plants. (A) $x$-fa1-2; (B) d-fa(c)-4. H, hematite; A, anhydrite; Q, quartz; C, calcite; I, illite; L, lime; and G, gypsum.

Glass phase (Figure 7B,D) is predominant among the inorganic phases of the CCPs from both power plants, and its proportion is higher in the bottom ashes relative to that of the fly ashes from Xilaifeng, which presents the opposite case for Damo power plant (Table 4 and Tables S7-S11). Generally, 
clay minerals can be transformed into other inorganic phases at high temperature, including glass, mullite, and cristobalite [58,59]. Due to relatively low furnace temperatures $\left(\sim 900{ }^{\circ} \mathrm{C}\right)$, mullite and cristobalite were not generated in the CCPs from Xilaifeng and Damo.
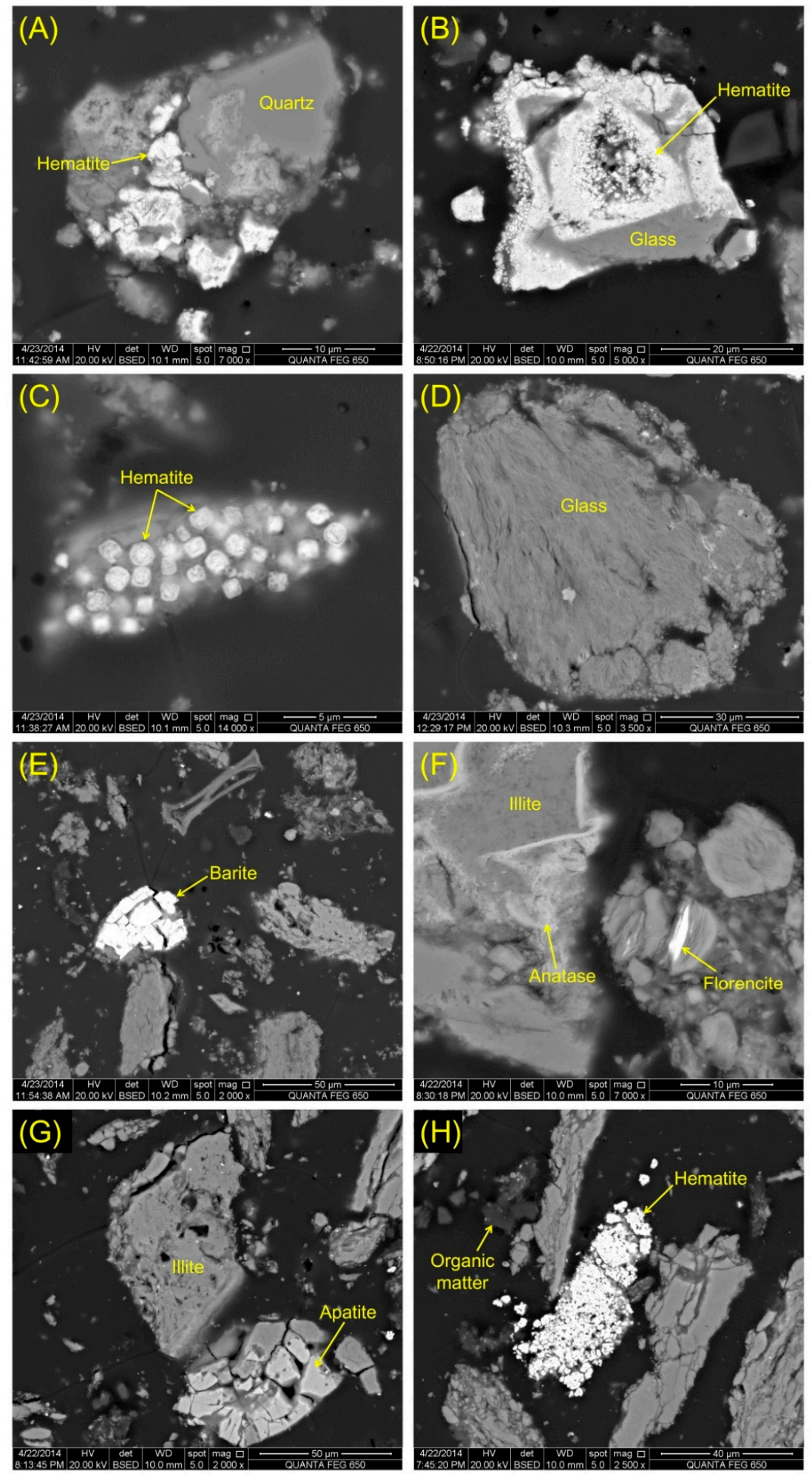

Figure 7. SEM backscattered images of minerals in the combustion products from the Xilaifeng and Damo power plants. (A) quartz; x-fa2-10; (B) hematite; d-fa(f)-6; (C) hematite; $x-f a 2-10$; (D) glass; $\mathrm{x}$-fa1-11; (E) barite; x-fa2-10; (F) florencite and anatase; d-fa(f)-6; (G) apatite; d-fa(f)-6; (H) organic matter and hematite; $d-f a(f)-6$. 
Because of its high melting point $\left(1750{ }^{\circ} \mathrm{C}\right)$, quartz barely reacts in the process of coal combustion. The contents of quartz in the bottom ashes from both power plants are much higher than those in the fly ashes, indicating the differentiation of quartz in CCPs and its preferential enrichment in the bottom ashes (Table 4 and Tables S7-S11). Furthermore, quartz content is higher in the coarse fly ashes from Damo (10.3\%; Table 4 and Table S10) relative to that of the fine fly ashes (7.1\%; Table 4 and Table S9). Irregular quartz is observed in the fly ash from Xilaifeng (Figure 7A).

The iron oxides in the CCPs are mainly derived from pyrites in the feed coals [60], and a relatively high temperature is required for the formation of magnetite (1000-1200 $\left.{ }^{\circ} \mathrm{C}\right)$ [61], which was not found in the CCPs from Xilaifeng and Damo due to lower furnace temperatures $\left(\sim 900{ }^{\circ} \mathrm{C}\right)$. Hematite is widespread in the CCPs from both power plants (Table 4 and Tables S7-S11; Figure 7A-C,H), generally well-crystallized, and in some cases present as framboids (Figure 7B,C). Besides, it shows a clear preferential enrichment in the fly ashes relative to the bottom ashes for both power plants (Table 4 and Tables S7-S11).

In most cases, anhydrite in the CCPs is formed through the reaction by calcite and organic sulfur/pyrite [60]. However, calcite content in the feed coals from Xilaifeng is very low $(<0.1 \%$; Table 2 and Table S3), and no gypsum is detected in the CCPs (Table 4 and Tables S7 and S8). It suggests that the abundant anhydrite in the CCPs from Xilaifeng was mostly generated from the dehydration of gypsum. In contrast, only a fraction of anhydrite is detected in the CCPs from Damo, indicating that most gypsum in the feed coals survived through combustion, and accounts for $2.5 \%$ and $1.5 \%$ of the inorganic phases of the fine and coarse fly ashes, respectively (Table 4, Tables S9 and S10).

Quite a proportion of illite (Figure 7F,G) exists in the CCPs from both power plants (Table 4 and Tables S7-S11) and is probably the residue of clay minerals in the feed coals due to incomplete combustion.

In addition, barite (Figure 7E), apatite (Figure 7G), florencite (Figure 7F), and anatase (Figure 7F) can be observed by using SEM-EDS in some cases of the fly ashes from Xilaifeng or Damo.

\subsection{Major and Trace Elements in the CCPS}

\subsubsection{Major Element Compositions of the CCPs}

The major elements in the CCPs are mainly derived from minerals in coal [62] and, in a few cases, from organic matter $[63,64]$. The CCPs from the two power plants are primarily composed of $\mathrm{SiO}_{2}$, $\mathrm{Al}_{2} \mathrm{O}_{3}, \mathrm{Fe}_{2} \mathrm{O}_{3}$, and $\mathrm{CaO}$ (Table 5 and Tables S12-S16). The enriched $\mathrm{Fe}_{2} \mathrm{O}_{3}$ in the CCPs is derived from the abundant pyrite in the feed coals (3.9\% and 7.3\%; Table 2), and the relatively low contents of $\mathrm{SiO}_{2}$ and $\mathrm{CaO}$ are attributed to the low proportions of quartz $(9.0 \%$ and $12.8 \%$; Table 2$)$ and gypsum $(2.7 \%$ and 1.9\%; Table 2) in the feed coals, respectively. Higher $\mathrm{CaO}$ contents in the fly and bottom ashes from Xilaifeng (9.15\% and 4.11\%; Table 5, Tables S12 and S13) relative to those from Damo (1.12\%-1.24\% and $0.27 \%$; Table 5 and Tables S14-S16) are due to massive limestone used in the desulfurization process at Xilaifeng. $\mathrm{Al}_{2} \mathrm{O}_{3}$ does not display clear differentiation in the CCPs from Xilaifeng or Damo (29.63\%-32.24\% and 29.31\%-30.47\%, respectively; Table 5 and Tables S12-S16), and the contents of $\mathrm{Na}_{2} \mathrm{O}, \mathrm{MgO}, \mathrm{P}_{2} \mathrm{O}_{5}, \mathrm{~K}_{2} \mathrm{O}, \mathrm{TiO}_{2}$, and $\mathrm{MnO}$ in the CCPs from both power plants are all low (Table 5 and Tables S12-S16).

According to the classification by ASTM Standard C618-19 [65], the fly ashes from both power plants can be defined as F-type fly ash, although the combustion of lower-rank coal generally produces C type (high-calcium) fly ash [66]. 
Table 5. Average concentrations of major $(\%)$ and trace $(\mu \mathrm{g} / \mathrm{g})$ elements in the coal combustion products (CCPs) from the Xilaifeng and Damo power plants.

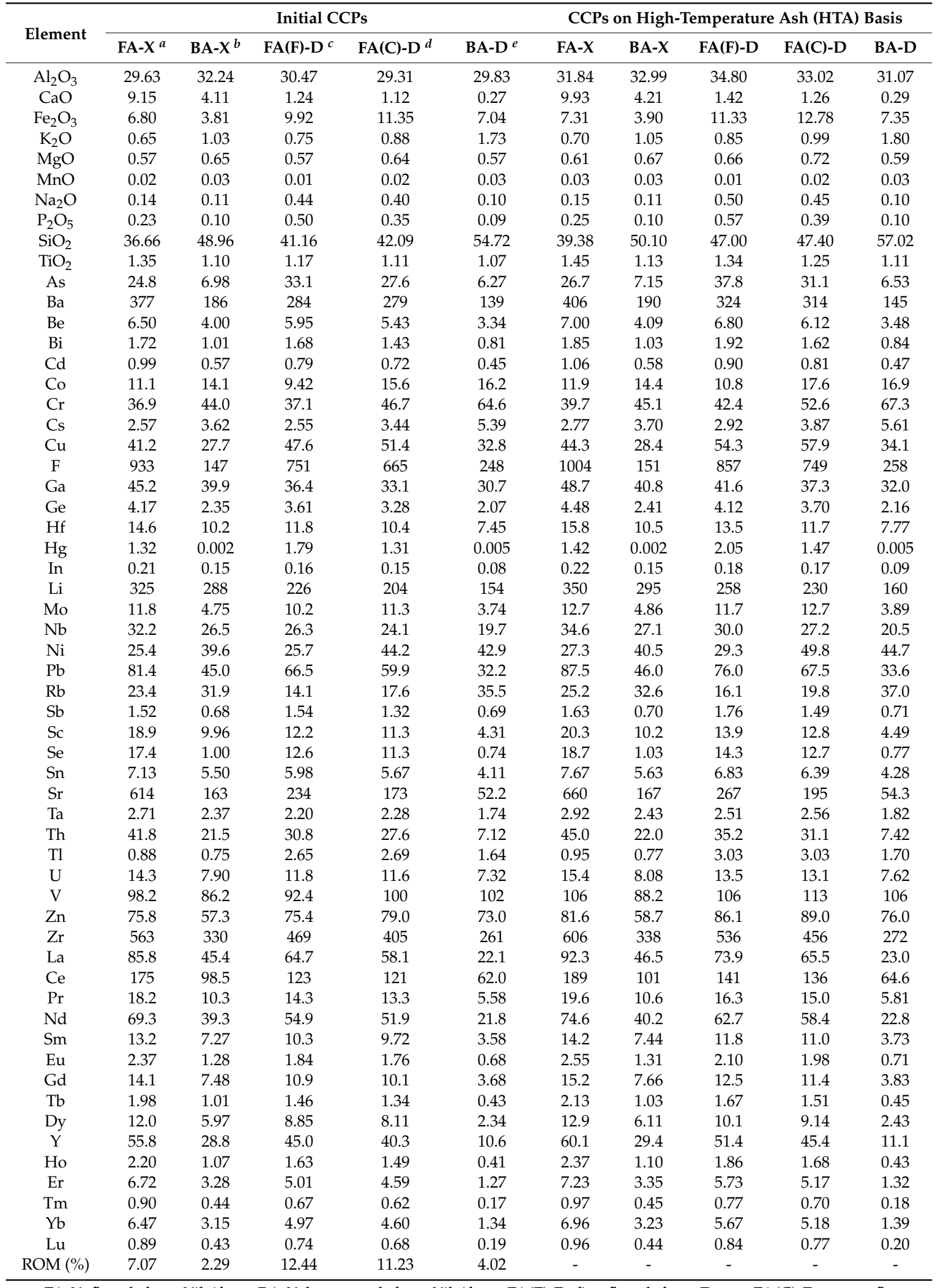

FA-X, fly ash from Xilaifeng; BA-X, bottom ash from Xilaifeng; FA(F)-D, fine fly ash from Damo; FA(C)-D, coarse fly ash from Damo; BA-D, bottom ash from Damo; ROM, residual organic matter. ${ }^{a}$, average of 28 fly ash samples; $b$, average of 28 bottom ash samples; ${ }^{c}$, average of 11 fine fly ash samples; ${ }^{d}$, average of 11 coarse fly ash samples;

${ }^{e}$, average of 12 bottom ash samples. 


\subsubsection{Distribution of Trace Elements in the CCPs}

Compared with those in the feed coals (Table 3, Tables S5 and S6), concentrations of most trace elements in the fly and bottom ashes from Xilaifeng (except for F, Se, Sr, and $\mathrm{Hg}$ ) and Damo (except for $\mathrm{F}, \mathrm{As}$, Se, $\mathrm{Rb}, \mathrm{Sr}, \mathrm{Mo}, \mathrm{Cs}, \mathrm{Ba}, \mathrm{Hg}$, Bi, and Th) are elevated (Table 5 and Tables S12-S16). In the present study, $f / b$ value (ratio of element concentration in the fly ash to that in the bottom ash) is applied to describe element distribution in the CCPs [48]. Considering varying contents of carbon residue in the $C C P s,{ }^{*} f / b$ value, the ratio of element concentration in the fly ash to that in the bottom ash eliminating the influence of carbon residue, is also used in this study.

$$
\begin{gathered}
f / b=[X]_{f} /[X]_{b} \\
* f / b=[X /(1-\mathrm{ROM})]_{f} /[X /(1-\mathrm{ROM})]_{b}
\end{gathered}
$$

where $[X]_{f}$ and $[X]_{b}$ are the concentrations of a certain element in the fly and bottom ashes, respectively; ROM is the content of residual organic matter in the fly ash or bottom ash determined by high-temperature ashing.

Furthermore, the relative enrichment (RE) coefficient is applied to describe the degree of enrichment of a certain element through combustion [48].

$$
\mathrm{RE}=\left([X]_{a} /[X]_{c}\right) \times A_{a d}
$$

where $[X]_{a}$ represents the concentration of a certain element in the fly ash or bottom ash; $[X]_{c}$ represents the concentration of a certain element in the feed coal; $A_{a d}$ represents the air-dried ash yield of the feed coal. $\mathrm{RE}<1$ means the depletion of a certain element in the fly ash or bottom ash, RE $>1$ means the elevation of a certain element, and $\mathrm{RE}=1$ means that a certain element is neither enriched nor depleted.

Except for $\mathrm{V}, \mathrm{Cr}, \mathrm{Co}, \mathrm{Ni}, \mathrm{Rb}$, and $\mathrm{Cs}$, the ${ }^{*} f / b$ values of other trace elements are all above 1 , suggesting their preferential enrichment in the fly ashes relative to the bottom ashes (Table 6; Figure 8). The fly ash is of high adsorption capacity due to the large specific surface area; thus, As, Se, $\mathrm{Hg}$ and other volatile elements are highly enriched in the fly ashes (Table 6; Figure 8), which possibly results in adverse environmental effect. In addition, organically associated elements and those that exist in the submicron and nano-sized minerals in coal can be concentrated in the fine fly ashes during combustion. Nonvolatile elements, such as $\mathrm{Ba}$ and $\mathrm{Na}$, in the present study, apply to this case (Table 6; Figure 8). For the Damo Power Plant, ${ }^{*} f(f) / b$ is higher than ${ }^{*} f(c) / b$ for most elements, indicating that they are more enriched in the fine fly ashes relative to coarse fly ashes (Table 6; Figure 8), which is in accordance with the studies by Meij [67] and Querol et al., [68].

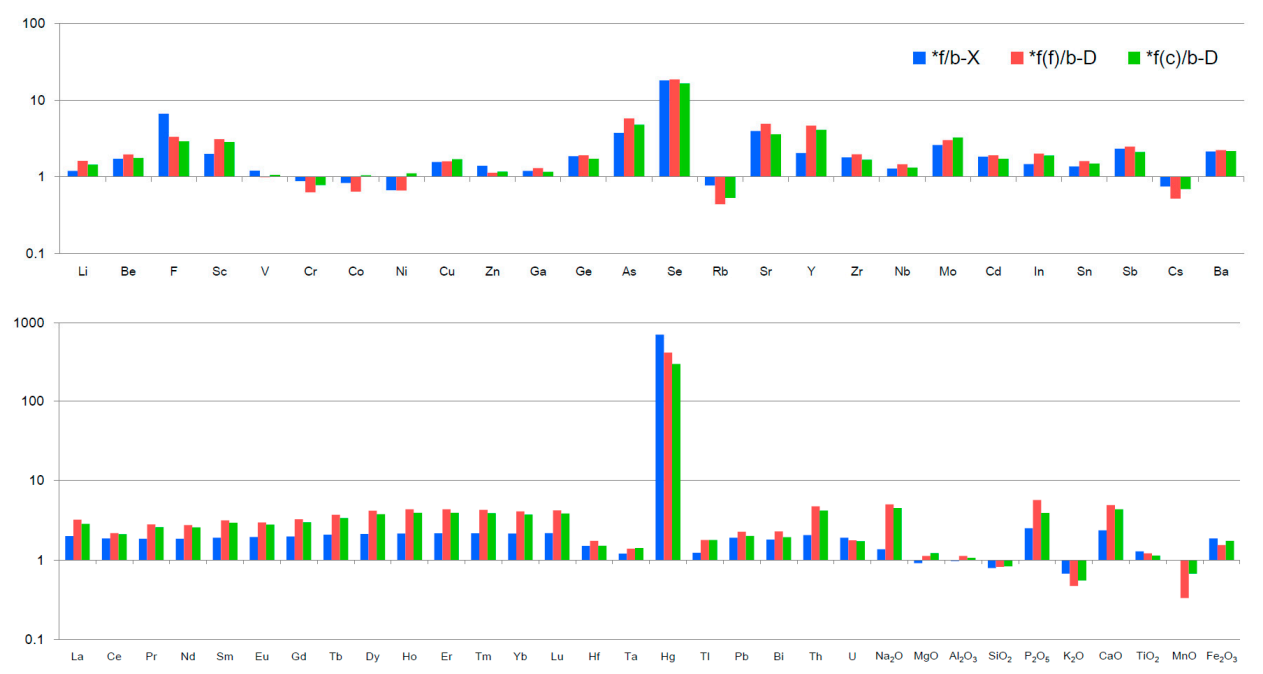

Figure 8. Average ratios of element concentrations in the fly ash vs. bottom ash from the Xilaifeng (X) and Damo (D) power plants. 
Table 6. Average ratios of element concentrations in the fly ash vs. bottom ash and relative enrichment (RE) coefficient of elements for the Xilaifeng and Damo power plants.

\begin{tabular}{|c|c|c|c|c|c|c|c|c|c|c|c|}
\hline \multirow{2}{*}{ Element } & \multicolumn{4}{|c|}{ Xilaifeng } & \multicolumn{7}{|c|}{ Damo } \\
\hline & $f / b$ & ${ }^{*} f / b$ & RE-f & RE-b & $f(f) / b$ & $f(c) / b$ & ${ }^{*} f(f) / b$ & ${ }^{*} f(c) / b$ & RE-f(f) & RE-f(c) & RE-b \\
\hline $\mathrm{Al}_{2} \mathrm{O}_{3}$ & 0.92 & 0.97 & 0.79 & 0.86 & 1.02 & 0.98 & 1.12 & 1.06 & 0.89 & 0.86 & 0.87 \\
\hline $\mathrm{CaO}$ & 2.23 & 2.36 & 11.81 & 5.31 & 4.59 & 4.15 & 4.90 & 4.34 & 1.67 & 1.50 & 0.36 \\
\hline $\mathrm{Fe}_{2} \mathrm{O}_{3}$ & 1.78 & 1.87 & 1.28 & 0.72 & 1.41 & 1.61 & 1.54 & 1.74 & 1.21 & 1.39 & 0.86 \\
\hline $\mathrm{K}_{2} \mathrm{O}$ & 0.63 & 0.67 & 0.66 & 1.05 & 0.43 & 0.51 & 0.47 & 0.55 & 0.53 & 0.62 & 1.21 \\
\hline $\mathrm{MgO}$ & 0.88 & 0.91 & 1.01 & 1.15 & 1.00 & 1.12 & 1.12 & 1.22 & 1.06 & 1.19 & 1.06 \\
\hline $\mathrm{MnO}$ & 0.67 & 1.00 & 1.06 & 1.59 & 0.33 & 0.67 & 0.33 & 0.67 & 0.48 & 0.97 & 1.45 \\
\hline $\mathrm{Na}_{2} \mathrm{O}$ & 1.27 & 1.36 & 1.06 & 0.83 & 4.40 & 4.00 & 5.00 & 4.50 & 4.26 & 3.87 & 0.97 \\
\hline $\mathrm{P}_{2} \mathrm{O}_{5}$ & 2.30 & 2.50 & 1.11 & 0.48 & 5.56 & 3.89 & 5.70 & 3.90 & 1.42 & 1.00 & 0.26 \\
\hline $\mathrm{SiO}_{2}$ & 0.75 & 0.79 & 0.71 & 0.95 & 0.75 & 0.77 & 0.82 & 0.83 & 0.79 & 0.81 & 1.05 \\
\hline $\mathrm{TiO}_{2}$ & 1.23 & 1.28 & 0.93 & 0.76 & 1.09 & 1.04 & 1.21 & 1.13 & 0.94 & 0.89 & 0.86 \\
\hline As & 3.55 & 3.73 & 1.98 & 0.56 & 5.28 & 4.41 & 5.79 & 4.77 & 2.04 & 1.70 & 0.39 \\
\hline $\mathrm{Ba}$ & 2.03 & 2.14 & 1.72 & 0.85 & 2.04 & 2.00 & 2.23 & 2.16 & 0.84 & 0.82 & 0.41 \\
\hline $\mathrm{Be}$ & 1.63 & 1.71 & 1.11 & 0.69 & 1.78 & 1.63 & 1.95 & 1.76 & 1.11 & 1.01 & 0.62 \\
\hline $\mathrm{Bi}$ & 1.70 & 1.80 & 1.21 & 0.71 & 2.07 & 1.77 & 2.29 & 1.93 & 0.97 & 0.82 & 0.47 \\
\hline $\mathrm{Cd}$ & 1.74 & 1.83 & 1.19 & 0.69 & 1.76 & 1.60 & 1.91 & 1.72 & 1.23 & 1.12 & 0.70 \\
\hline Co & 0.79 & 0.83 & 0.92 & 1.16 & 0.58 & 0.97 & 0.64 & 1.05 & 0.77 & 1.28 & 1.32 \\
\hline $\mathrm{Cr}$ & 0.84 & 0.88 & 0.90 & 1.07 & 0.57 & 0.72 & 0.63 & 0.78 & 0.71 & 0.89 & 1.24 \\
\hline Cs & 0.71 & 0.75 & 0.81 & 1.14 & 0.47 & 0.64 & 0.52 & 0.69 & 0.40 & 0.54 & 0.84 \\
\hline $\mathrm{Cu}$ & 1.49 & 1.56 & 1.16 & 0.78 & 1.45 & 1.57 & 1.59 & 1.70 & 0.79 & 0.85 & 0.54 \\
\hline $\mathrm{F}$ & 6.35 & 6.66 & 1.83 & 0.29 & 3.03 & 2.68 & 3.32 & 2.90 & 0.94 & 0.83 & 0.31 \\
\hline $\mathrm{Ga}$ & 1.13 & 1.19 & 0.95 & 0.84 & 1.19 & 1.08 & 1.30 & 1.16 & 1.22 & 1.10 & 1.03 \\
\hline $\mathrm{Ge}$ & 1.77 & 1.86 & 1.43 & 0.81 & 1.74 & 1.58 & 1.91 & 1.71 & 0.95 & 0.87 & 0.55 \\
\hline Hf & 1.43 & 1.50 & 1.08 & 0.75 & 1.59 & 1.40 & 1.74 & 1.51 & 1.20 & 1.05 & 0.75 \\
\hline $\mathrm{Hg}$ & 660 & 710 & 2.18 & 0.00 & 358 & 262 & 410 & 294 & 1.42 & 1.04 & 0.00 \\
\hline In & 1.40 & 1.47 & 1.11 & 0.79 & 2.00 & 1.88 & 2.00 & 1.89 & 1.11 & 1.04 & 0.55 \\
\hline $\mathrm{Li}$ & 1.13 & 1.19 & 0.90 & 0.80 & 1.47 & 1.33 & 1.61 & 1.44 & 2.45 & 2.21 & 1.66 \\
\hline Mo & 2.48 & 2.60 & 1.46 & 0.59 & 2.74 & 3.01 & 3.01 & 3.26 & 1.30 & 1.43 & 0.48 \\
\hline $\mathrm{Nb}$ & 1.21 & 1.28 & 0.86 & 0.71 & 1.33 & 1.22 & 1.46 & 1.32 & 1.02 & 0.93 & 0.76 \\
\hline $\mathrm{Ni}$ & 0.64 & 0.67 & 0.80 & 1.25 & 0.60 & 1.03 & 0.66 & 1.11 & 0.90 & 1.55 & 1.50 \\
\hline $\mathrm{Pb}$ & 1.81 & 1.90 & 1.48 & 0.82 & 2.07 & 1.86 & 2.26 & 2.01 & 1.09 & 0.98 & 0.53 \\
\hline $\mathrm{Rb}$ & 0.74 & 0.77 & 0.75 & 1.02 & 0.40 & 0.49 & 0.44 & 0.53 & 0.24 & 0.29 & 0.59 \\
\hline $\mathrm{Sb}$ & 2.24 & 2.33 & 1.46 & 0.65 & 2.23 & 1.91 & 2.48 & 2.10 & 1.35 & 1.16 & 0.61 \\
\hline Sc & 1.90 & 1.99 & 1.20 & 0.63 & 2.82 & 2.63 & 3.09 & 2.84 & 2.44 & 2.27 & 0.86 \\
\hline Se & 17.35 & 18.13 & 2.26 & 0.13 & 16.97 & 15.26 & 18.62 & 16.52 & 1.62 & 1.46 & 0.10 \\
\hline Sn & 1.30 & 1.36 & 1.05 & 0.81 & 1.45 & 1.38 & 1.60 & 1.49 & 1.01 & 0.96 & 0.69 \\
\hline $\mathrm{Sr}$ & 3.77 & 3.96 & 1.87 & 0.50 & 4.49 & 3.31 & 4.92 & 3.58 & 1.68 & 1.24 & 0.37 \\
\hline $\mathrm{Ta}$ & 1.14 & 1.20 & 1.09 & 0.96 & 1.26 & 1.31 & 1.38 & 1.41 & 1.01 & 1.05 & 0.80 \\
\hline Th & 1.95 & 2.05 & 1.15 & 0.59 & 4.32 & 3.88 & 4.74 & 4.19 & 1.95 & 1.75 & 0.45 \\
\hline $\mathrm{Tl}$ & 1.17 & 1.23 & 1.14 & 0.97 & 1.62 & 1.64 & 1.78 & 1.78 & 1.12 & 1.14 & 0.70 \\
\hline $\mathrm{U}$ & 1.81 & 1.90 & 1.13 & 0.63 & 1.62 & 1.59 & 1.77 & 1.72 & 1.12 & 1.10 & 0.69 \\
\hline $\mathrm{V}$ & 1.14 & 1.20 & 1.11 & 0.97 & 0.91 & 0.98 & 0.99 & 1.06 & 0.78 & 0.85 & 0.87 \\
\hline $\mathrm{Zn}$ & 1.32 & 1.39 & 1.11 & 0.84 & 1.03 & 1.08 & 1.13 & 1.17 & 1.39 & 1.45 & 1.34 \\
\hline $\mathrm{Zr}$ & 1.71 & 1.79 & 1.12 & 0.66 & 1.79 & 1.55 & 1.97 & 1.67 & 1.28 & 1.10 & 0.71 \\
\hline $\mathrm{La}$ & 1.89 & 1.99 & 1.33 & 0.71 & 2.94 & 2.64 & 3.22 & 2.85 & 1.91 & 1.72 & 0.65 \\
\hline $\mathrm{Ce}$ & 1.78 & 1.87 & 1.23 & 0.69 & 1.99 & 1.95 & 2.18 & 2.11 & 1.38 & 1.36 & 0.70 \\
\hline $\operatorname{Pr}$ & 1.76 & 1.85 & 1.27 & 0.72 & 2.56 & 2.39 & 2.81 & 2.59 & 1.96 & 1.83 & 0.77 \\
\hline $\mathrm{Nd}$ & 1.76 & 1.85 & 1.28 & 0.72 & 2.51 & 2.38 & 2.75 & 2.57 & 1.97 & 1.86 & 0.78 \\
\hline $\mathrm{Sm}$ & 1.81 & 1.90 & 1.31 & 0.72 & 2.89 & 2.72 & 3.16 & 2.94 & 2.12 & 1.99 & 0.73 \\
\hline $\mathrm{Eu}$ & 1.85 & 1.95 & 1.24 & 0.67 & 2.71 & 2.59 & 2.96 & 2.79 & 2.07 & 1.98 & 0.76 \\
\hline $\mathrm{Gd}$ & 1.89 & 1.98 & 1.27 & 0.67 & 2.96 & 2.75 & 3.25 & 2.98 & 2.20 & 2.04 & 0.74 \\
\hline $\mathrm{Tb}$ & 1.96 & 2.07 & 1.29 & 0.66 & 3.40 & 3.12 & 3.71 & 3.36 & 2.43 & 2.23 & 0.72 \\
\hline Dy & 2.02 & 2.12 & 1.31 & 0.65 & 3.78 & 3.47 & 4.16 & 3.76 & 2.53 & 2.32 & 0.67 \\
\hline $\mathrm{Y}$ & 1.94 & 2.04 & 1.26 & 0.65 & 4.24 & 3.80 & 4.65 & 4.11 & 2.73 & 2.44 & 0.64 \\
\hline Ho & 2.06 & 2.15 & 1.29 & 0.63 & 3.98 & 3.63 & 4.33 & 3.91 & 2.63 & 2.40 & 0.66 \\
\hline Er & 2.05 & 2.16 & 1.30 & 0.64 & 3.94 & 3.61 & 4.34 & 3.92 & 2.63 & 2.41 & 0.67 \\
\hline $\mathrm{Tm}$ & 2.05 & 2.16 & 1.29 & 0.63 & 3.94 & 3.65 & 4.28 & 3.89 & 2.70 & 2.50 & 0.69 \\
\hline $\mathrm{Yb}$ & 2.05 & 2.15 & 1.29 & 0.63 & 3.71 & 3.43 & 4.08 & 3.73 & 2.73 & 2.53 & 0.74 \\
\hline $\mathrm{Lu}$ & 2.07 & 2.18 & 1.27 & 0.62 & 3.89 & 3.58 & 4.20 & 3.85 & 2.98 & 2.74 & 0.77 \\
\hline
\end{tabular}

Notes: $f / b$, fly ash/bottom ash; ${ }^{*} f / b$, fly ash/bottom ash eliminating the influence of carbon residue; RE-f/b, relative enrichment (RE) coefficient for fly ash or bottom ash; $f(f) / b$, fine fly ash/bottom ash; $f(c) / b$, coarse fly ash/bottom ash; ${ }^{*} f(f) / b$, fine fly ash/bottom ash eliminating the influence of carbon residue; ${ }^{*} f(c) / b$, coarse fly ash/bottom ash eliminating the influence of carbon residue; $R E-f(f) / f(c)$, relative enrichment $(R E)$ coefficient for fine fly ash or coarse fly ash. 
The elements with ${ }^{*} f / b$ value below $1(\mathrm{Cr}, \mathrm{Co}, \mathrm{Ni}, \mathrm{Rb}, \mathrm{Cs}, \mathrm{Si}$, and K; Table 6; Figure 8) are more enriched in the bottom ashes, and those with ${ }^{*} / / b$ value around $1(\mathrm{~V}, \mathrm{Mg}$, and $\mathrm{Al}$; Table 6; Figure 8) do not clearly differentiate between fly and bottom ashes. They all have little relation with the specific surface area of CCP particles. The comparison of their relative enrichment (RE) coefficients for the bottom ashes is shown in Figure 9. Chromium, $\mathrm{Co}$, and Ni in coal have similar modes of occurrence, and they mostly exist in clay minerals, pyrite, and organic matter $[69,70]$. Due to their high boiling points $\left(2672,2870\right.$, and $2732{ }^{\circ} \mathrm{C}$, respectively), they display preferential enrichment in the bottom ashes, though they can occur in the organics, which is consistent with the findings of Clarke and Sloss [71] and Dai et al. [72]. Rubidium, Cs, Si, and $\mathrm{K}$ in coal primarily exist in the kaolinite, quartz, and illite [62], and their derived minerals by combustion are all refractory minerals, such as metakaolinite, spinel, cristobalite, mullite, tridymite, etc. Therefore, $\mathrm{Rb}, \mathrm{Cs}, \mathrm{Si}$, and $\mathrm{K}$ are more enriched in the bottom ashes. Vanadium, $\mathrm{Mg}$, and $\mathrm{Al}$ mostly occur in clay minerals [62] that are refractory during coal combustion (some are associated with the organic matters $[63,64]$ that also become the components of the CCPs); thus, they barely differentiate among CCPs.

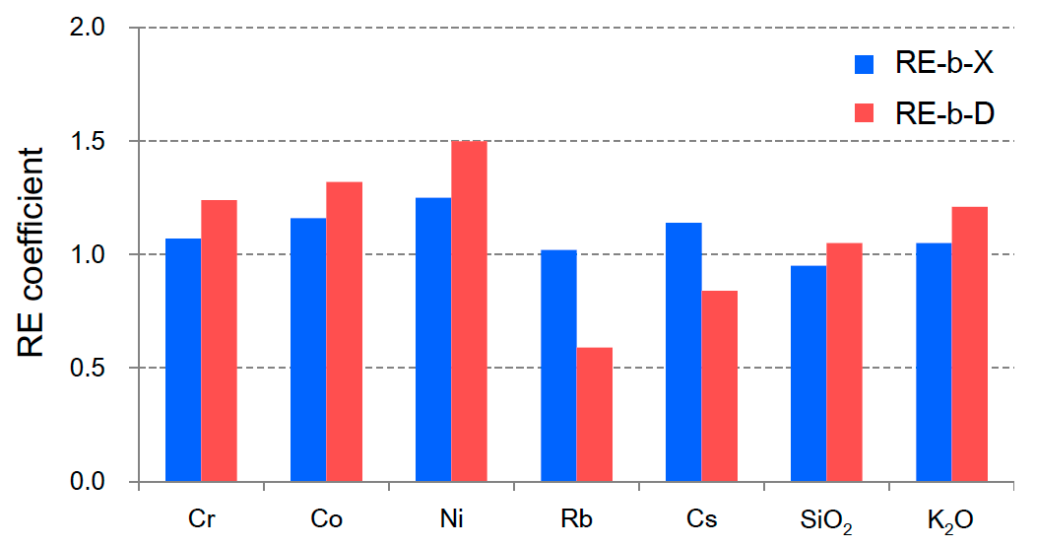

Figure 9. Average relative enrichment (RE) coefficient of selected elements $\left({ }^{*} f / b-X<1\right.$ and ${ }^{*} f(f) / b$-D $<1$; Table 6) in the bottom ashes from Xilaifeng (X) and Damo (D).

In order to present the degree of elementary differentiation between fly and bottom ashes, the elements with ${ }^{*} / b$ value above 1 (Table 6 ) can be arbitrarily classified into three groups: Group I $\left(1 \leq{ }^{*} f / b \leq 2.5\right)$ : Li, Be, Sc, V, Cu, Zn, Ga, Ge, Sb, Zr, Nb, Cd, In, Sn, Ba, Hf, Ta, Tl, Pb, Bi, Th, U, Na, Mg, $\mathrm{Al}, \mathrm{P}, \mathrm{Ca}, \mathrm{Ti}, \mathrm{Mn}, \mathrm{Fe}$, and REY; Group II $\left({ }^{*} f / b>2.5\right)$ : F, As, Sr, and Mo; Group III $\left({ }^{*} f / b \gg 2.5\right)$ : Se and Hg.

Most elements (Group I) are slightly enriched in the fly ashes relative to the bottom ashes, indicating a certain degree of volatility of these elements. Group II elements have stronger volatility. Fluorine has a very low boiling point $\left(-188.12{ }^{\circ} \mathrm{C}\right)$, and it evaporates at the very beginning of combustion and concentrates on the surface of fly ash particles. The relative enrichment (RE) coefficients of $\mathrm{F}$ in the fly ashes (Xilaifeng: 1.83; Damo: 0.94 and 0.83; Table 6; Figure 10A) for both power plants are much higher than those for the bottom ashes (Xilaifeng: 0.29; Damo: 0.31; Table 6). The lower RE coefficients of F in the fly ashes from Damo relative to that of Xilaifeng are due to the loss of gaseous fluorine during combustion. Arsenic in coal is generally associated with pyrite [73-77], but it also occurs in some other minerals (e.g., Tl-As sulfides, getchellite, clay minerals, phosphate minerals, and arsenic minerals [62]) and organic matter $[63,78]$. In the process of combustion, the mineral components in the fly ash and arsenic oxides can form stable complexes [79], so, As can be fixed in the fly ash, such as in the form of complex As-bearing oxides [52]. Besides, gaseous arsenic compounds (including arsenic oxides and organic compounds) can be significantly adsorbed by the fly ash due to its large surface area [80]. Molybdenum and $\mathrm{Sr}$ can form compounds with relatively low boiling points that volatilize during combustion; thus, Mo and Sr are more enriched in the fly ashes. 
(A)

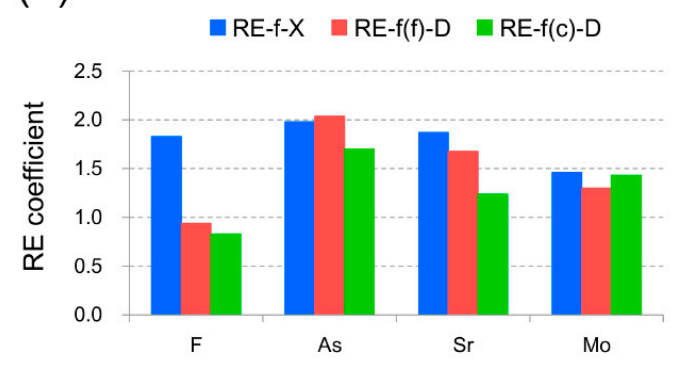

(B)

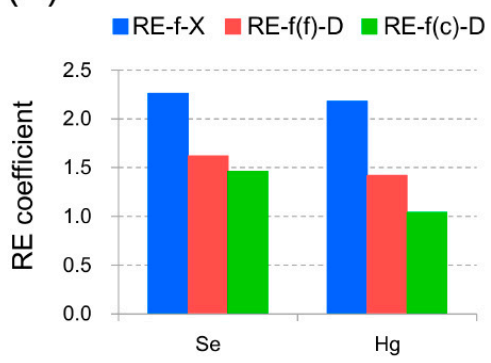

Figure 10. Average relative enrichment (RE) coefficient of elements $\left((\mathbf{A}),{ }^{*} f / b>2.5 ;(\mathbf{B}),{ }^{*} f / b \gg 2.5\right)$ in the fly ashes from Xilaifeng (X) and Damo (D).

Group III elements (Se and $\mathrm{Hg}$ ) are significantly more enriched in the fly ashes relative to the bottom ashes, and their relative enrichment (RE) coefficients for the fly ashes from Xilaifeng are higher than those of Damo (Table 6; Figure 10B). Selenium primarily occurs in the pyrite, and it also associates with the organic matter [81-84]. Selenium itself and its compounds are of quite low boiling points. Pyrite is the major carrier of $\mathrm{Hg}$ in coal $[83,84]$, and it also exists in other minerals, such as calcite and chlorite [85], clausthalite [82], kleinite and cinnabar [86], and getchellite [87]. In addition, $\mathrm{Hg}$ can be almost completely volatilized at $800{ }^{\circ} \mathrm{C}$ [88]. Therefore, Se and $\mathrm{Hg}$ can be adsorbed by the fly ashes or released into the atmosphere, depending on the working conditions of the dust-collection systems of the power plants.

\subsubsection{Comparison of Trace Elements in the CCPs and Coal HTAs}

In order to further characterize the immigration and redistribution of trace elements in the process of combustion, element concentrations in the CCPs from both power plants and laboratory high-temperature coal ashes (HTAs) are compared in the present study. The enrichment factors of trace elements in the CCPs from Xilaifeng and Damo are seen in Figure 11, normalized by laboratory coal ashes (Table 3). It is noted that most trace elements (Xilaifeng: excluding $\mathrm{Li}, \mathrm{Cr}, \mathrm{Co}, \mathrm{Ni}, \mathrm{Rb}, \mathrm{Nb}$, and Cs; Damo: excluding $\mathrm{Li}, \mathrm{V}, \mathrm{Cr}, \mathrm{Co}, \mathrm{Ni}, \mathrm{Cu}, \mathrm{Zn}, \mathrm{Ga}, \mathrm{Rb}, \mathrm{Cs}$, and $\mathrm{Ba}$ ) are more enriched in the (fine) fly ashes, relative to the HTAs, followed by the bottom ashes (Figure 11). This relates to their volatilities in the process of combustion. Generally, elements and their compounds can evaporate during coal combustion, and they can be adsorbed and condensed on the surface of the CCP particles when the temperature decreases. Besides, the furnace temperatures $\left(\sim 900^{\circ} \mathrm{C}\right)$ are higher than the laboratory ashing temperature $\left(750{ }^{\circ} \mathrm{C}\right)$. Thus, some elements can be more easily released from the feed coals, at a certain degree, resulting in higher concentrations in the fly ashes. Accordingly, element enrichment in the fly ashes corresponds to depletion in the bottom ashes.

Like most trace elements, rare earth elements and yttrium (REY) are more enriched in the fly ashes relative to the HTAs, and they are depleted in the bottom ashes (Figure 12). It demonstrates their volatilities, to some extent, in the process of coal combustion. The distribution patterns of REY in the CCPs from Xilaifeng and Damo are quite different. The REY in the fly ash or bottom ash from Xilaifeng do not display clear differentiation (Figure 12A). The REY in the fine fly ash and coarse fly ash from Damo are of very similar distribution patterns (H-type, based on the classification by Seredin and Dai [15]) with negative Ce anomaly and slightly positive $Y$ anomaly, but REY barely differentiate in the bottom ash (Figure 12B). In most cases, REY are difficult to differentiate during combustion, and therefore, they should display similar distribution patterns in the CCPs and HTAs [52]. The distinct REY distribution patterns between the fly and bottom ashes from Damo are probably resulted from the particular combustion technique of the Damo power plant. 


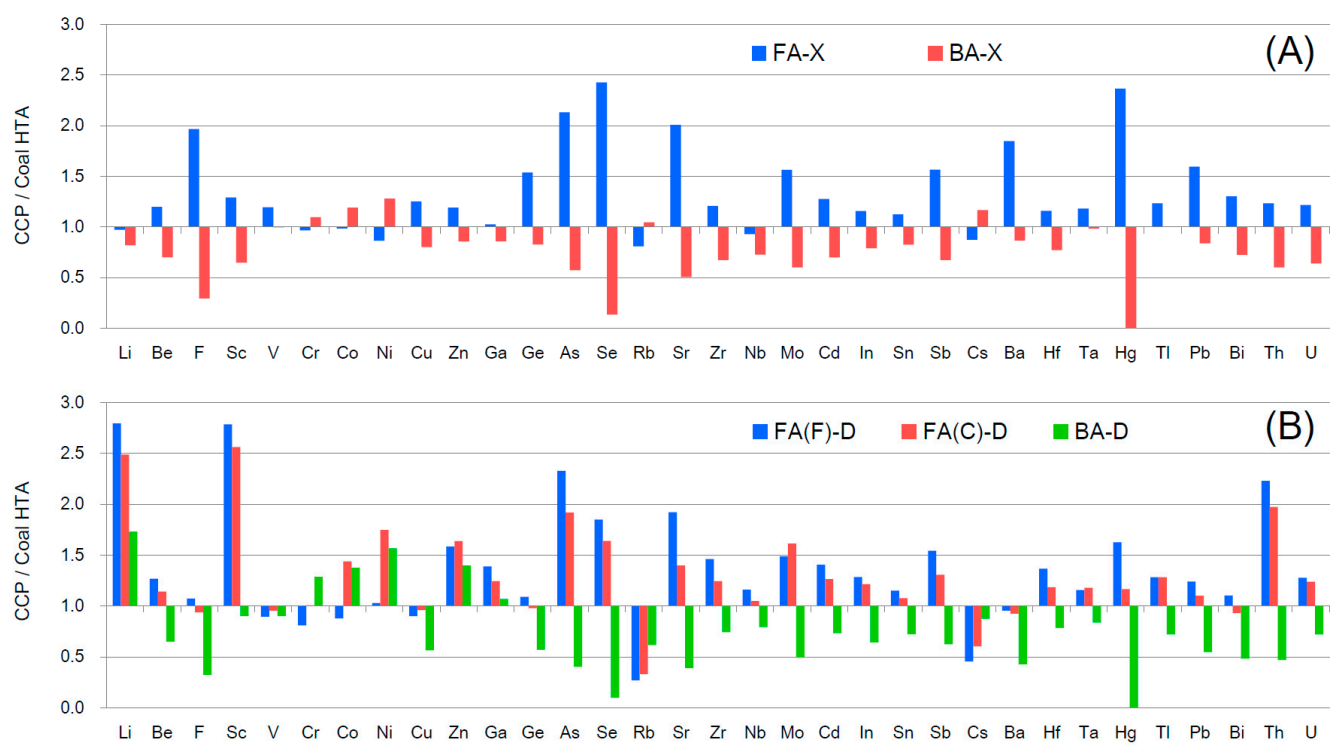

Figure 11. Average enrichment factors of trace elements in the CCPs (ash basis) from the Xilaifeng (A) and Damo (B) power plants, relative to laboratory coal ashes.

(A)

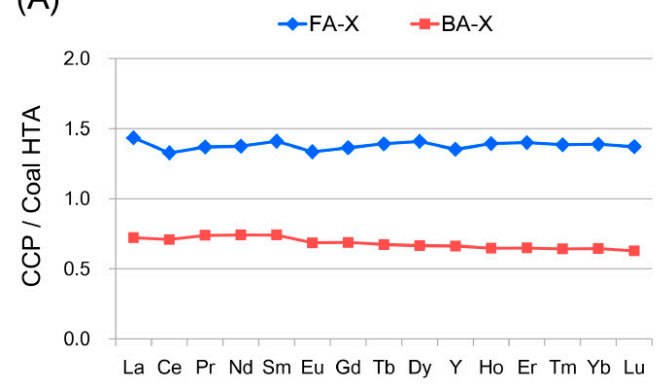

(B)

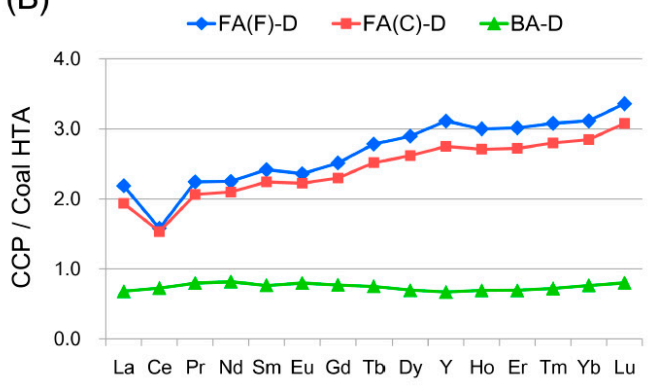

Figure 12. Distribution patterns of REY in CCPs (ash basis; on average) from the Xilaifeng (A) and Damo (B) power plants. REY concentrations are normalized to laboratory coal ashes.

\section{Conclusions}

The feed coals from the Xilaifeng and Damo power plants are both of high ash yield, and medium and high total sulfur content. The minerals in the feed coals are primarily composed of kaolinite, quartz, illite, pyrite, and, to a lesser extent, gypsum and anatase. In addition to the elevated incompatible elements ( $\mathrm{Nb}, \mathrm{Ta}, \mathrm{Zr}, \mathrm{Hf}$, and $\mathrm{Th}), \mathrm{Li}$ and $\mathrm{Hg}$ are enriched in the feed coals from Xilaifeng and Damo, respectively. Rare earth elements and yttrium (REY) in the feed coals from Xilaifeng are more enriched than those of Damo.

Inorganic phases of CCPs from both power plants are mainly composed of glass phase, quartz, hematite, illite, and anhydrite. Compared with the feed coals, concentrations of most trace elements in the CCPs are elevated, and they display preferential enrichment in the fly ashes relative to the bottom ashes $\left({ }^{*} f / b>1\right)$, especially F, As, Sr, Mo, Se, and $\mathrm{Hg}\left({ }^{*} f / b>2.5\right)$. Furthermore, most trace elements are more enriched in the (fine) fly ashes relative to the laboratory high-temperature coal ashes (HTAs). The REY barely differentiate in either the fly ash or bottom ash from Xilaifeng. In contrast, the REY in the fly ashes from Damo display H-type distribution patterns, with negative Ce and slightly positive $\mathrm{Y}$ anomalies.

Attention should be paid to the enriched toxic elements (including F, As, and $\mathrm{Hg}$ ) in the fly ashes from both power plants, due to possible adverse environmental impacts. The future work will focus on the influence of toxic elements and reasonable utilization of CCPs derived from the Wuda coal. 
Supplementary Materials: The following are available online at http://www.mdpi.com/2075-163X/10/4/323/s1, Table S1: Samples collected for the present study; Table S2: Proximate analysis (\%) and total sulfur (\%) of feed coals from the Xilaifeng and Damo power plants; Table S3: Mineralogical compositions of the low temperature ashes (LTAs) of feed coals (wt.\%) for the Xilaifeng Power Plant by XRD and Siroquant analysis; Table S4: Mineralogical compositions of the low-temperature ashes (LTAs) of feed coals (wt.\%) for the Damo Power Plant by XRD and Siroquant analysis; Table S5: Concentrations of trace $(\mu \mathrm{g} / \mathrm{g})$ and major $(\%)$ elements in the feed coals from the Xilaifeng Power Plant; Table S6: Concentrations of trace $(\mu \mathrm{g} / \mathrm{g})$ and major $(\%)$ elements in the feed coals from the Damo Power Plant; Table S7: Mineralogical compositions of the fly ashes from the Xilaifeng Power Plant (\%); Table S8: Mineralogical compositions of the bottom ashes from the Xilaifeng Power Plant (\%); Table S9: Mineralogical compositions of the fine fly ashes from the Damo Power Plant (\%); Table S10: Mineralogical compositions of the coarse fly ashes from the Damo Power Plant (\%); Table S11: Mineralogical compositions of the bottom ashes from the Damo Power Plant (\%); Table S12: Concentrations of trace ( $\mu \mathrm{g} / \mathrm{g})$ and major $(\%)$ elements in the fly ashes from the Xilaifeng Power Plant; Table S13: Concentrations of trace ( $\mu \mathrm{g} / \mathrm{g})$ and major $(\%)$ elements in the bottom ashes from the Xilaifeng Power Plant; Table S14: Concentrations of trace $(\mu \mathrm{g} / \mathrm{g})$ and major $(\%)$ elements in the fine fly ashes from the Damo Power Plant; Table S15: Concentrations of trace $(\mu \mathrm{g} / \mathrm{g})$ and major $(\%)$ elements in the coarse fly ashes from the Damo Power Plant; Table S16: Concentrations of trace $(\mu \mathrm{g} / \mathrm{g})$ and major (\%) elements in the bottom ashes from the Damo Power Plant.

Author Contributions: Conceptualization, Q.W. and W.S.; methodology, W.S.; writing-original draft, Q.W. All authors have read and agreed to the published version of the manuscript.

Funding: This study was financially supported by the National Natural Science Foundation of China (Nos. U1810202, 41902169, and 91962220) and the 111 Project (No. B17042).

Acknowledgments: The two anonymous reviewers, academic editor (Stavros Kalaitzidis), and collection editors (Shifeng Dai and David French) are deeply appreciated for their valuable comments and suggestions for the manuscript.

Conflicts of Interest: The authors declare no conflict of interest.

\section{References}

1. International Energy Agency. Market Report Series: Coal 2019-Analysis and Forecast to 2024; International Energy Agency: Paris, France, 2019.

2. Jankowski, J.; Ward, C.R.; French, D.; Groves, S. Mobility of trace elements from selected Australian fly ashes and its potential impact on aquatic ecosystems. Fuel 2006, 85, 243-256. [CrossRef]

3. Jones, K.B.; Ruppert, L.F.; Swanson, S.M. Leaching of elements from bottom ash, economizer fly ash, and fly ash from two coal-fired power plants. Int. J. Coal Geol. 2012, 94, 337-348. [CrossRef]

4. Koralegedara, N.H.; Al-Abed, S.R.; Arambewela, M.K.J.; Dionysiou, D.D. Impact of leaching conditions on constituents release from Flue Gas Desulfurization Gypsum (FGDG) and FGDG-soil mixture. J. Hazard. Mater. 2017, 324, 83-93. [CrossRef] [PubMed]

5. Monroy Sarmiento, L.; Roessler, J.G.; Townsend, T.G. Trace element mobility from coal combustion residuals exposed to landfill leachate. J. Hazard. Mater. 2019, 365, 962-970. [CrossRef]

6. Querol, X.; Umaña, J.C.; Alastuey, A.; Ayora, C.; Lopez-Soler, A.; Plana, F. Extraction of soluble major and trace elements from fly ash in open and closed leaching systems. Fuel 2001, 80, 801-813. [CrossRef]

7. Ward, C.R.; French, D.; Jankowski, J.; Dubikova, M.; Li, Z.; Riley, K.W. Element mobility from fresh and long-stored acidic fly ashes associated with an Australian power station. Int. J. Coal Geol. 2009, 80, 224-236. [CrossRef]

8. Zhang, S.; Dai, S.; Finkelman, R.B.; Graham, I.T.; French, D.; Hower, J.C.; Li, X. Leaching characteristics of alkaline coal combustion by-products: A case study from a coal-fired power plant, Hebei Province, China. Fuel 2019, 255, 115710. [CrossRef]

9. Zhao, L.; Dai, S.; Finkelman, R.B.; French, D.; Graham, I.T.; Yang, Y.; Li, J.; Yang, P. Leaching behavior of trace elements from fly ashes of five Chinese coal power plants. Int. J. Coal Geol. 2020, 219, 103381. [CrossRef]

10. Dai, S.; Zhou, Y.; Zhang, M.; Wang, X.; Wang, J.; Song, X.; Jiang, Y.; Luo, Y.; Song, Z.; Yang, Z.; et al. A new type of $\mathrm{Nb}(\mathrm{Ta})-\mathrm{Zr}(\mathrm{Hf})-\mathrm{REE}-\mathrm{Ga}$ polymetallic deposit in the late Permian coal-bearing strata, eastern Yunnan, southwestern China Possible economic significance and genetic implications. Int. J. Coal Geol. 2010, 83, 55-63. [CrossRef]

11. Taggart, R.K.; Hower, J.C.; Dwyer, G.S.; Hsu-Kim, H. Trends in the rare earth element content of U.S.-Based coal combustion fly ashes. Environ. Sci. Technol. 2016, 50, 5919-5926. [CrossRef] 
12. Kolker, A.; Scott, C.; Hower, J.C.; Vazquez, J.A.; Lopano, C.L.; Dai, S. Distribution of rare earth elements in coal combustion fly ash, determined by SHRIMP-RG ion microprobe. Int. J. Coal Geol. 2017, 184, 1-10. [CrossRef]

13. Lin, R.; Howard, B.H.; Roth, E.A.; Bank, T.L.; Granite, E.J.; Soong, Y. Enrichment of rare earth elements from coal and coal by-products by physical separations. Fuel 2017, 200, 506-520. [CrossRef]

14. Wang, Z.; Dai, S.; Zou, J.; French, D.; Graham, I.T. Rare earth elements and yttrium in coal ash from the Luzhou power plant in Sichuan, Southwest China: Concentration, characterization and optimized extraction. Int. J. Coal Geol. 2019, 203, 1-14. [CrossRef]

15. Seredin, V.V.; Dai, S. Coal deposits as potential alternative sources for lanthanides and yttrium. Int. J. Coal Geol. 2012, 94, 67-93. [CrossRef]

16. Seredin, V.V.; Dai, S.; Sun, Y.; Chekryzhov, I.Y. Coal deposits as promising sources of rare metals for alternative power and energy-efficient technologies. Appl. Geochem. 2013, 31, 1-11. [CrossRef]

17. Dai, S.; Finkelman, R.B. Coal as a promising source of critical elements: Progress and future prospects. Int. J. Coal Geol. 2018, 186, 155-164. [CrossRef]

18. Dai, S.; Yan, X.; Ward, C.R.; Hower, J.C.; Zhao, L.; Wang, X.; Zhao, L.; Ren, D.; Finkelman, R.B. Valuable elements in Chinese coals: A review. Int. Geol. Rev. 2018, 60, 590-620. [CrossRef]

19. Dai, S.; Ren, D.; Chou, C.-L.; Li, S.; Jiang, Y. Mineralogy and geochemistry of the No. 6 Coal (Pennsylvanian) in the Junger Coalfield, Ordos Basin, China. Int. J. Coal Geol. 2006, 66, 253-270. [CrossRef]

20. Dai, S.; Li, D.; Chou, C.-L.; Zhao, L.; Zhang, Y.; Ren, D.; Ma, Y.; Sun, Y. Mineralogy and geochemistry of boehmite-rich coals: New insights from the Haerwusu Surface Mine, Jungar Coalfield, Inner Mongolia, China. Int. J. Coal Geol. 2008, 74, 185-202. [CrossRef]

21. Dai, S.; Jiang, Y.; Ward, C.R.; Gu, L.; Seredin, V.V.; Liu, H.; Zhou, D.; Wang, X.; Sun, Y.; Zou, J.; et al. Mineralogical and geochemical compositions of the coal in the Guanbanwusu Mine, Inner Mongolia, China: Further evidence for the existence of an $\mathrm{Al}$ (Ga and REE) ore deposit in the Jungar Coalfield. Int. J. Coal Geol. 2012, 98, 10-40. [CrossRef]

22. Dai, S.; Li, T.; Jiang, Y.; Ward, C.R.; Hower, J.C.; Sun, J.; Liu, J.; Song, H.; Wei, J.; Li, Q.; et al. Mineralogical and geochemical compositions of the Pennsylvanian coal in the Hailiushu Mine, Daqingshan Coalfield, Inner Mongolia, China: Implications of sediment-source region and acid hydrothermal solutions. Int. J. Coal Geol. 2015, 137, 92-110. [CrossRef]

23. Zhao, L.; Ward, C.R.; French, D.; Graham, I.T.; Dai, S.; Yang, C.; Xie, P.; Zhang, S. Origin of a kaolinite-NH4-illite-pyrophyllite-chlorite assemblage in a marine-influenced anthracite and associated strata from the Jincheng Coalfield, Qinshui Basin, Northern China. Int. J. Coal Geol. 2018, 185, 61-78. [CrossRef]

24. Zhao, L.; Dai, S.; Nechaev, V.P.; Nechaeva, E.V.; Graham, I.T.; French, D. Enrichment origin of critical elements (Li and rare earth elements) and a Mo-U-Se-Re assemblage in Pennsylvanian anthracite from the Jincheng Coalfield, southeastern Qinshui Basin, northern China. Ore Geol. Rev. 2019, 115, 103184. [CrossRef]

25. Zhao, L.; Dai, S.; Nechaev, V.P.; Nechaeva, E.V.; Graham, I.T.; French, D.; Sun, J. Enrichment of critical elements (Nb-Ta-Zr-Hf-REE) within coal and host rocks from the Datanhao mine, Daqingshan Coalfield, northern China. Ore Geol. Rev. 2019, 111, 102951. [CrossRef]

26. Kang, J.; Zhao, L.; Wang, X.; Song, W.; Wang, P.; Wang, R.; Li, T.; Sun, J.; Jia, S.; Zhu, Q. Abundance and geological implication of rare earth elements and yttrium in coals from the Suhaitu Mine, Wuda Coalfield, northern China. Energy Explor. Exploit. 2014, 32, 873-890. [CrossRef]

27. Chen, J.; Chen, P.; Yao, D.; Liu, Z.; Wu, Y.; Liu, W.; Hu, Y. Mineralogy and geochemistry of Late Permian coals from the Donglin Coal Mine in the Nantong coalfield in Chongqing, southwestern China. Int. J. Coal Geol. 2015, 149, 24-40. [CrossRef]

28. Dai, S.; Ren, D.; Zhou, Y.; Chou, C.; Wang, X.; Zhao, L.; Zhu, X. Mineralogy and geochemistry of a superhigh-organic-sulfur coal, Yanshan Coalfield, Yunnan, China: Evidence for a volcanic ash component and influence by submarine exhalation. Chem. Geol. 2008, 255, 182-194. [CrossRef]

29. Dai, S.; Seredin, V.V.; Ward, C.R.; Hower, J.C.; Xing, Y.; Zhang, W.; Song, W.; Wang, P. Enrichment of U-Se-Mo-Re-V in coals preserved within marine carbonate successions: Geochemical and mineralogical data from the Late Permian Guiding Coalfield, Guizhou, China. Miner. Depos. 2015, 50, 159-186. [CrossRef] 
30. Dai, S.; Zhang, W.; Seredin, V.V.; Ward, C.R.; Hower, J.C.; Song, W.; Wang, X.; Li, X.; Zhao, L.; Kang, H.; et al. Factors controlling geochemical and mineralogical compositions of coals preserved within marine carbonate successions: A case study from the Heshan Coalfield, southern China. Int. J. Coal Geol. 2013, 109, 77-100. [CrossRef]

31. Liu, J.; Yang, Z.; Yan, X.; Ji, D.; Yang, Y.; Hu, L. Modes of occurrence of highly-elevated trace elements in superhigh-organic-sulfur coals. Fuel 2015, 156, 190-197. [CrossRef]

32. Medunić, G.; Grigore, M.; Dai, S.; Berti, D.; Hochella, M.F.; Mastalerz, M.; Valentim, B.; Guedes, A.; Hower, J.C. Characterization of superhigh-organic-sulfur Raša coal, Istria, Croatia, and its environmental implication. Int. J. Coal Geol. 2020, 217, 103344. [CrossRef]

33. Han, D.; Yang, Q. Coal Geology of China, Vol. 2; Publishing House of China Coal Industry: Beijing, China, 1980. (In Chinese)

34. Liu, G. Permo-Carboniferous paleography and coal accumulation and their tectonic control in North China and South China continental plates. Int. J. Coal Geol. 1990, 16, 73-117. [CrossRef]

35. Dai, S.; Ren, D.; Tang, Y.; Shao, L.; Li, S. Distribution, isotopic variation and origin of sulfur in coals in the Wuda coalfield, Inner Mongolia, China. Int. J. Coal Geol. 2002, 51, 237-250. [CrossRef]

36. Shan, B.; Wang, G.; Cao, F.; Wu, D.; Liang, W.; Sun, R. Mercury emission from underground coal fires in the mining goaf of the Wuda Coalfield, China. Ecotox. Environ. Saf. 2019, 182, 109409. [CrossRef] [PubMed]

37. Cao, Q.; Liang, H.; Chen, Y.; Li, Z.; Liu, H. Distribution of mercury content in topsoil of coal base, Wuda, China. J. Min. Sci. Technol. 2018, 3, 315-322, (In Chinese with English abstract).

38. ASTM Standard D3173-11. Test Method for Moisture in the Analysis Sample of Coal and Coke; ASTM International: West Conshohocken, PA, USA, 2011.

39. ASTM Standard D3174-11. Test Method for Ash in the Analysis Sample of Coal and Coke; ASTM International: West Conshohocken, PA, USA, 2011.

40. ASTM Standard D3175-11. Test Method for Volatile Matter in the Analysis Sample of Coal and Coke; ASTM International: West Conshohocken, PA, USA, 2011.

41. ASTM Standard D3177-02. Test Methods for Total Sulfur in the Analysis Sample of Coal and Coke; ASTM International: West Conshohocken, PA, USA, 2002; (Reapproved 2007).

42. Taylor, J.C. Computer programs for standardless quantitative analysis of minerals using the full powder diffraction profile. Powder Diffract. 1991, 6, 2-9. [CrossRef]

43. Rietveld, H.M. A profile refinement method for nuclear and magnetic structures. J. Appl. Crystallogr. 1969, 2, 65-71. [CrossRef]

44. Dai, S.; Wang, X.; Zhou, Y.; Hower, J.C.; Li, D.; Chen, W.; Zhu, X. Chemical and mineralogical compositions of silicic, mafic, and alkali tonsteins in the late Permian coals from the Songzao Coalfield, Chongqing, Southwest China. Chem. Geol. 2011, 282, 29-44. [CrossRef]

45. Li, X.; Dai, S.; Zhang, W.; Li, T.; Zheng, X.; Chen, W. Determination of As and Se in coal and coal combustion products using closed vessel microwave digestion and collision/reaction cell technology (CCT) of inductively coupled plasma mass spectrometry (ICP-MS). Int. J. Coal Geol. 2014, 124, 1-4. [CrossRef]

46. Dai, S.; Hower, J.C.; Ward, C.R.; Guo, W.; Song, H.; O’Keefe, J.M.K.; Xie, P.; Hood, M.M.; Yan, X. Elements and phosphorus minerals in the middle Jurassic inertinite-rich coals of the Muli Coalfield on the Tibetan Plateau. Int. J. Coal Geol. 2015, 144-145, 23-47. [CrossRef]

47. ASTM Standard D5987-96. Standard Test Method for Total Fluorine in Coal and Coke by Pyrohydrolytic Extraction and Ion Selective Electrode or Ion Chromatograph Methods; ASTM International: West Conshohocken, PA, USA, 2002; (Reapproved 2007).

48. Dai, S.; Zhao, L.; Peng, S.; Chou, C.L.; Wang, X.; Zhang, Y.; Li, D.; Sun, Y. Abundances and distribution of minerals and elements in high-alumina coal fly ash from the Jungar Power Plant, Inner Mongolia, China. Int. J. Coal Geol. 2010, 81, 320-332. [CrossRef]

49. Guedes, A.; Valentim, B.; Prieto, A.C.; Sanz, A.; Flores, D.; Noronha, F. Characterization of fly ash from a power plant and surroundings by micro-Raman spectroscopy. Int. J. Coal Geol. 2008, 73, 359-370. [CrossRef]

50. Huggins, F.; Goodarzi, F. Environmental assessment of elements and polyaromatic hydrocarbons emitted from a Canadian coal-fired power plant. Int. J. Coal Geol. 2009, 77, 282-288. [CrossRef]

51. Mardon, S.M.; Hower, J.C.; O'Keefe, J.M.K.; Marks, M.N.; Hedges, D.H. Coal combustion by-product quality at two stoker boilers: Coal source vs. fly ash collection system design. Int. J. Coal Geol. 2008, 75, 248-254. [CrossRef] 
52. Dai, S.; Seredin, V.V.; Ward, C.R.; Jiang, J.; Hower, J.C.; Song, X.; Jiang, Y.; Wang, X.; Gornostaeva, T.; $\mathrm{Li}, \mathrm{X}$; ; et al. Composition and modes of occurrence of minerals and elements in coal combustion products derived from high-Ge coals. Int. J. Coal Geol. 2014, 121, 79-97. [CrossRef]

53. Dai, S.; Ren, D.; Chou, C.L.; Finkelman, R.B.; Seredin, V.V.; Zhou, Y. Geochemistry of trace elements in Chinese coals: A review of abundances, genetic types, impacts on human health, and industrial utilization. Int. J. Coal Geol. 2012, 94, 3-21. [CrossRef]

54. Ketris, M.P.; Yudovich, Y.E. Estimations of Clarkes for Carbonaceous biolithes: World average for trace element contents in black shales and coals. Int. J. Coal Geol. 2009, 78, 135-148. [CrossRef]

55. Taylor, S.R.; McLennan, S.M. The Continental Crust: Its Composition and Evolution; Blackwell: Oxford, UK, 1985; p. 312.

56. Dai, S.; Graham, I.T.; Ward, C.R. A review of anomalous rare earth elements and yttrium in coal. Int. J. Coal Geol. 2016, 159, 82-95. [CrossRef]

57. Hower, J.C.; Groppo, J.G.; Graham, U.M.; Ward, C.R.; Kostova, I.; Maroto-Valer, M.M.; Dai, S. Coal-derived unburned carbons in fly ash: A review. Int. J. Coal Geol. 2017, 179, 11-27. [CrossRef]

58. Vassilev, S.V.; Vassileva, C.G. Mineralogy of combustion wastes from coal-fired power stations. Fuel Process. Technol. 1996, 47, 261-280. [CrossRef]

59. Spears, D.A. Role of clay minerals in UK coal combustion. Appl. Clay Sci. 2000, 16, 87-95. [CrossRef]

60. Vassileva, C.G.; Vassilev, S.V. Behaviour of inorganic matter during heating of Bulgarian coals: 1. Lignites. Fuel Process. Technol. 2005, 86, 1297-1333. [CrossRef]

61. Jak, E.; Degterov, S.; Hayes, P.C.; Pelton, A.D. Thermodynamic modeling of the system $\mathrm{Al}_{2} \mathrm{O}_{3}-\mathrm{SiO}_{2}-\mathrm{CaO}-\mathrm{FeO}-\mathrm{Fe}_{2} \mathrm{O}_{3}$ to predict the flux requirements for coal ash slags. Fuel 1998, 77, 77-84. [CrossRef]

62. Finkelman, R.B.; Dai, S.; French, D. The importance of minerals in coal as the hosts of chemical elements: A review. Int. J. Coal Geol. 2019, 212, 103251. [CrossRef]

63. Dai, S.; Hower, J.C.; Finkelman, R.B.; Graham, I.T.; French, D.; Ward, C.R.; Eskenazy, G.; Wei, Q.; Zhao, L. Organic associations of non-mineral elements in coal: A review. Int. J. Coal Geol. 2020, 218, 103347. [CrossRef]

64. Liu, J.; Ward, C.R.; Graham, I.T.; French, D.; Dai, S.; Song, X. Modes of occurrence of non-mineral inorganic elements in lignites from the Mile Basin, Yunnan Province, China. Fuel 2018, 222, 146-155. [CrossRef]

65. ASTM Standard C618-19. Standard Specification for Coal Fly Ash and Raw or Calcined Natural Pozzolan for Use in Concrete; ASTM International: West Conshohocken, PA, USA, 2019.

66. Hower, J.C. Petrographic examination of coal-combustion fly ash. Int. J. Coal Geol. 2012, 92, 90-97. [CrossRef]

67. Meij, R. Trace element behaviors in coal-fired power plants. Fuel Process. Technol. 1994, 39, 199-217. [CrossRef]

68. Querol, X.; Juan, R.; Lopez-Soler, A.; Fernandez-Turiel, J.; Ruiz, C.R. Mobility of trace elements from coal and combustion wastes. Fuel 1996, 75, 821-838. [CrossRef]

69. Huggins, F.E.; Huffman, G.P. How do lithophile elements occur in organic association in bituminous coals? Int. J. Coal Geol. 2004, 58, 193-204. [CrossRef]

70. Zhao, L.; Ward, C.; French, D.; Graham, I. Major and Trace element geochemistry of coals and intra-seam claystones from the Songzao Coalfield, SW China. Minerals 2015, 5, 870-893. [CrossRef]

71. Clarke, L.B.; Sloss, L.L. Trace Elements-Emissions from Coal Combustion and Gasification; IEA Coal Research: London, UK, 1992.

72. Dai, S.; Zhao, L.; Hower, J.C.; Johnston, M.N.; Song, W.; Wang, P.; Zhang, S. Petrology, mineralogy, and chemistry of size-fractioned fly ash from the Jungar Power Plant, Inner Mongolia, China, with emphasis on the distribution of rare earth elements. Energy Fuels 2014, 28, 1502-1514. [CrossRef]

73. Ruppert, L.F.; Minkin, J.A.; McGee, J.J.; Cecil, C.B. An unusual occurrence of arsenic-bearing pyrite in the Upper Freeport coal bed, west-central Pennsylvania. Energy Fuels 1992, 6, 120-125. [CrossRef]

74. Eskenazy, G.M. Geochemistry of arsenic and antimony in Bulgarian coals. Chem. Geol. 1995, 119, $239-254$. [CrossRef]

75. Hower, J.C.; Robertson, J.D.; Wong, A.S.; Eble, C.F.; Ruppert, L.F. Arsenic and lead concentrations in the pond creek and fire clay coal beds, Eastern Kentucky coal field. Appl. Geochem. 1997, 12, 281-289. [CrossRef]

76. Ward, C.R. Mineralogical analysis in hazard assessment. In Geological Hazards-the Impact to Mining; Doyle, R., Moloney, J., Eds.; Coalfield Geology Council of New South Wales: Newcastle, Australia, 2001; pp. 81-88.

77. Yudovich, Y.E.; Ketris, M.P. Arsenic in coal: A review. Int. J. Coal Geol. 2005, 61, 141-196. [CrossRef] 
78. Wei, Q.; Rimmer, S.M. Acid solubility and affinities of trace elements in the high-Ge coals from Wulantuga (Inner Mongolia) and Lincang (Yunnan Province), China. Int. J. Coal Geol. 2017, 178, 39-55. [CrossRef]

79. Ratafia-Brown, J.A. Overview of trace element partitioning in flames and furnaces of utility coal-fired boilers. Fuel Process. Technol. 1994, 39, 139-158. [CrossRef]

80. Lu, J.; Sun, J.; Zhao, C. Occurrence of As in coal and its behavior during coal combustion. Coal Geol. Explor. 2003, 31, 6-9, (In Chinese with English abstract).

81. Bai, X.; Li, W.; Chen, W. The study on distribution of selenium in Chinese coals and its washability. J. China Coal Soc. 2003, 281, 69-73, (In Chinese with English abstract).

82. Hower, J.C.; Robertson, J.D. Clausthalite in coal. Int. J. Coal Geol. 2003, 534, 219-225. [CrossRef]

83. Dai, S.; Wang, X.; Seredin, V.V.; Hower, J.C.; Ward, C.R.; O'Keefe, J.M.K.; Huang, W.; Li, T.; Li, X.; Liu, H.; et al. Petrology, mineralogy, and geochemistry of the Ge-rich coal from the Wulantuga Ge ore deposit, Inner Mongolia, China: New data and genetic implications. Int. J. Coal Geol. 2012, 90-91, 72-99. [CrossRef]

84. Dai, S.; Yang, J.; Ward, C.R.; Hower, J.C.; Liu, H.; Garrison, T.M.; French, D.; O’Keefe, J.M.K. Geochemical and mineralogical evidence for a coal-hosted uranium deposit in the Yili Basin, Xinjiang, northwestern China. Ore Geol. Rev. 2015, 70, 1-30. [CrossRef]

85. Zhang, J.; Ren, D.; Zheng, C.; Zeng, R.; Chou, C.-L.; Liu, J. Trace element abundances in major minerals of Late Permian coals from southwestern Guizhou Province, China. Int. J. Coal Geol. 2002, 53, 55-64. [CrossRef]

86. Brownfield, M.E.; Affolter, R.H.; Cathcart, J.D.; Johnson, S.Y.; Brownfield, I.K.; Rice, C.A. Geologic setting and characterization of coals and the modes of occurrence of selected elements from the Franklin coal zone, Puget Group, John Henry No. 1 mine, King County, Washington, USA. Int. J. Coal Geol. 2005, 63, 247-275. [CrossRef]

87. Dai, S.; Zeng, R.; Sun, Y. Enrichment of arsenic, antimony, mercury, and thallium in a late Permian anthracite from Xingren, Guizhou, southwest China. Int. J. Coal Geol. 2006, 66, 217-226. [CrossRef]

88. Rizeq, R.G.; Hansell, D.W.; Seeker, W.R. Predictions of metals emissions and partitioning in coal-fired combustion systems. Fuel Process. Technol. 1994, 39, 219-236. [CrossRef]

(C) 2020 by the authors. Licensee MDPI, Basel, Switzerland. This article is an open access article distributed under the terms and conditions of the Creative Commons Attribution (CC BY) license (http://creativecommons.org/licenses/by/4.0/). 